\title{
Características Espectrais da Nasalidade
}

\section{Maira Cristina Quirino de Souza}

Dissertação apresentada ao Programa de Pós-Graduação Interunidades em Bioengenharia - Escola de Engenharia de São Carlos - Faculdade de Medicina de Ribeirão Preto e Instituto de Química de São Carlos da Universidade de São Paulo para a obtenção do título de Mestre em Bioengeharia.

ORIENTADOR: Prof. Dr. José Carlos Pereira

São Carlos - SP

2003 
Aos meus pais Jair e Niége com muito carinho. Agradeço ao apoio, ao amor e a confiança depositada em mim. Aos meus irmãos Marcelo e Maiara agradeço o incentivo e a amizade. Sem a ajuda de todos não teria concluído este trabalho. Amo muito todos vocês. 


\section{Agradecimentos}

- Ao meu orientador agradeço a excelente orientação, a compreensão, a paciência e a confiança depositada em mim.

- Agradeço a CAPES pelo auxílio financeiro.

- À secretaria Janete Ferreira Rodrigues dos Santos pela sua dedicação e por estar sempre disposta a resolver meus problemas.

- Aos meus amigos Daniel, Ricardo, Granato e Marcelo agradeço a companhia e amizade durante todo o meu mestrado.

- À minha amiga "Parê" sou muito grata pela amizade e preocupação que sempre demostrou por mim no decorrer do meu mestrado.

- Às fonoaudiólogas Jussara e Luciana pelos esclarecimentos pertinentes à àrea de fonoaudiologia e pela literatura sugerida.

- A todos os voluntários que se dispuseram a gravar as suas vozes. Sem estes, não seria possível a realização deste trabalho.

- Ao Sílvio, Mateus e Helena pela companhia. 
- À minha querida amiga Cláudia e ao Yuri, pelas tardes de café e pela amizade que sempre demonstraram por mim e à pequena Ana Clara que com seu sorriso de criança nos faz esquecer de todas as dificuldades enfrentadas nos dias difíceis.

- A todos os funcionários da Biblioteca Central pelo excelente atendimento. Sempre foram muito simpáticos, atenciosos e prestativos.

- À minha querida avó Idelfina (em memória) meu enorme carinho. Aos meus avós Belmiro, Nelson e Nilza pelos conselhos e pelo exemplo de vida que me deram.

- Dona Cidinha e Sr. Valdir agradeço pelo apoio.

- À Fabiana, Anália, Carol e César.

- Aos meus amigos Líria e Flávio.

- Aos meus amigos Sandra e Fábio.

- Em especial ao meu namorado Clodoaldo. 


\section{Lista de Figuras}

Figura 1 - Estruturas que compõe o aparelho respiratório

Figura 2 - Conjunto de músculos associados com a respiração 5

Figura 3 - Pregas vocais aduzidas e pregas vocais abduzidas 7

Figura 4 - Visualização das conchas nasais e seus respectivos meatos nasais 9

Figura 5 - Podemos observar as cavidades oral e nasal separada pelo palato 10

Figura 6 - Ossos da face: seio frontal, seio maxilar, seio etmoidal e seio esfenoidal 11

Figura 7 - Visualização das pregas vocais e da glote

Figura 8 - Cartilagens da laringe vistas posteriormente 13

Figura 9 - Cartilagens da laringe vistas de frente 14

Figura 10 - Visualização da cartilagem aritenóide 15

Figura 11 - Cartilagens laríngeas: epiglote, tireóide, aritenóides e cricóide 16

Figura 12 - Vista frontal do osso hióide 18 
Figura 13 - Visualização dos articuladores: lábio superior e inferior, dentes, língua e palato

Figura 14 - À esquerda vemos o palato duro e à direita o palato mole 20

Figura 15 - Arcada Dentária 20

Figura 16 - Posicionamento do trato vocal para produzir uma vogal 24

Figura 17 - Estruturas importantes que determinam a freqüência dos formantes 24

Figura 18 - Configurações do trato vocal e seus respectivos espectros vocálicos 25

Figura 19 - Visão lateral do esfincter velofaríngeo 27

Figura 20 - Posicionamento do Nasômetro 32

Figura 21 - Configuração do trato vocal durante a produção das vogais /a/, /i/, /u/ e /æ/ ..35

Figura 22 - Diagrama esquemático do mecanismo de produção da fala humana 41

Figura 23 - Diagrama em bloco da produção da fala humana 42

Figura 24 - Diagrama esquemático dos diversos parâmetros propostos na literatura 44

Figura 25 - Tela inicial exibida pelo programa “Análise de Voz 2.3”. 50

Figura 26 - Visualização da tela exibida pelo recurso "Comparação". 52

Figura 27 - Visualização da tela exibida pelo recurso "Análise” 53 
Figura 28 - Visualização da tela exibida pelo recurso "Analisador de Espectro"

Figura 29 - Porcentagens de Jitter. À esquerda vogal /a/ oral e a direita /a/ nasal

Figura 30 - Amostra do grupo masculino onde a porcentagem do parâmetro Jitter da vogal oral foi maior que o da vogal nasal. 63

Figura 31 - Amostra do grupo feminino onde a porcentagem do parâmetro Jitter da vogal nasal foi maior que o da vogal oral 63

Figura 32 - Amostra do grupo feminino onde a porcentagem do parâmetro Jitter da vogal oral foi bem maior que a da vogal nasal 64

Figura 33 - Amostra do grupo masculino onde a porcentagem do parâmetro Jitter da vogal nasal foi um pouco maior que a da vogal oral. 64

Figura 34 - Espectro vocálico feminino pronunciando a vogal /a/ oral (A. M. S.). 67

Figura 35 - Espectro vocálico feminino pronunciando a vogal /a/ nasal

$$
\text { (A. M. S.) }
$$

Figura 36 - Espectro vocálico feminino pronunciando a vogal /a/ oral

(M. C. Q. S.) 68

Figura 37 - Espectro vocálico feminino pronunciando a vogal /a/ nasal

(M. C. Q. S.) 68 
Figura 38 - Espectro vocálico masculino pronunciando a vogal /a/ oral

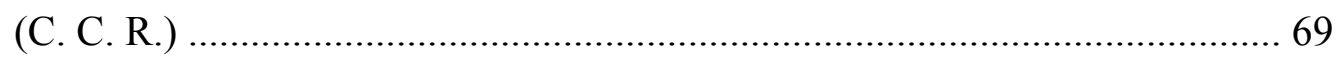

Figura 39 - Espectro vocálico masculino pronunciando a vogal /a/ nasal

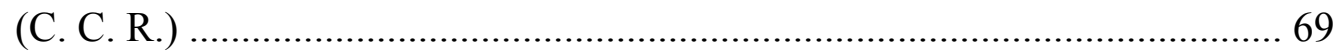

Figura 40 - Espectro vocálico masculino pronunciando a vogal /a/ oral

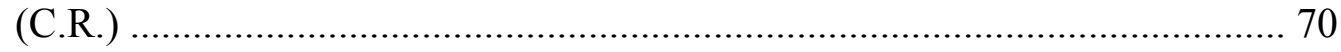

Figura 41 - Espectro vocálico masculino pronunciando a vogal /a/ nasal

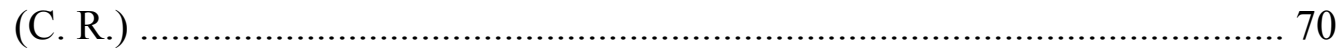




\section{Lista de Tabelas}

Tabela 1 - Análise do parâmetro Jitter para vozes do grupo feminino e masculino 59

Tabela 2 - Variação percentual de Jitter para as vozes do grupo feminino 60

Tabela 3 - Variação percentual de Jitter para as vozes do grupo masculino 61

Tabela 4 - Variação percentual média do parâmetro Jitter para os grupos feminino e masculino 62

Tabela 5 - Análise das anti-ressonâncias para as amostras dos grupos femininos e masculinos 66 


\section{Resumo}

O objetivo deste trabalho foi comparar as características espectrais de sons vocálicos quando pronunciada de maneira oral e nasal. A vogal escolhida é o /a/ sustentado por oferecer menor carga acústica para o sistema glotal.

A avaliação qualitativa das diferenças entre estas vogais foi analisada através do espectro vocálico. A quantificação das diferenças foi efetuada através de parâmetros acústicos da voz - nominalmente a Suavidade Espectral.

Os resultados encontrados demostraram que o espectro vocálico é um determinador de nasalidade eficiente por apresentar vales em freqüências características.

Uma futura quantificação destes vales certamente auxiliará os especialistas da área de voz a avaliar a nasalidade contida na voz.

Palavras-chaves: quantificação, nasalidade, parâmetros acústicos, espectro vocálico e aparelho fonatório 


\section{Abstract}

In this work oral and nasal voices are compared through their spectral characteristics. The chosen vowel is the sustained /a/ due to its lower acoustic load to the glottal system.

The differences between both vowels have been qualitatively evaluated through their spectral. These differences were quantified by the acoustic parameter of the voice namely the spectral flatness.

Results show that the vowel spectrum is very effective determine nasality in the voice due to the valley that happens in the spectrum.

A quantification of this valley will certainly help voice specialists to evaluate nasality in the voice.

Keyword: evaluation, nasality, acoustic parameters, voice spectrum, system phonatory and voice. 


\section{Sumário}

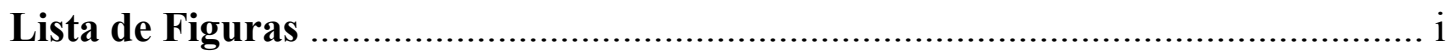

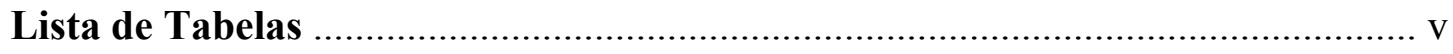

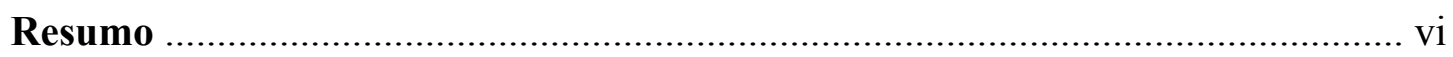

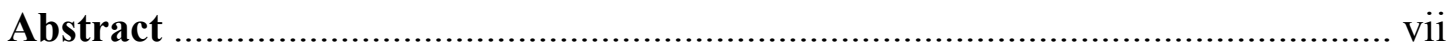

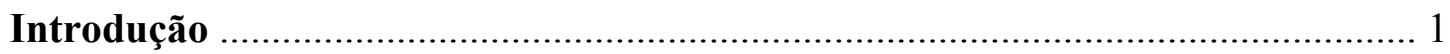

Capítulo 1 - Anatomia dos Aparelhos: Respiratório, Fonatório e Articulador

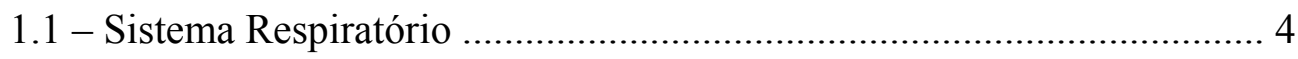

1.1.1 - Anatomia Nasal e Cavidade Nasal ............................................. 7

1.1.2 - Seios Paranasais ........................................................................ 10

1.2 - Sistema Fonatório ................................................................. 12

1.2.1 - Anatomia da Laringe ........................................................... 12

1.2.2 - Cartilagens e Músculos ......................................................... 13

1.2.3 - Osso Hióide ............................................................................... 17

1.3 - Sistema Articulatório .................................................................. 18

\section{Capítulo 2 - Mecanismo Vocal}

2.1 - Fo, Harmônicos e Ressonância ...................................................... 22

2.2 - Formante Vocálico ...................................................................... 23 
Capítulo 3 - Estruturas Velofaríngeas

3.1 - Esfíncter Velofaríngeo

Capítulo 4 - Avanços Tecnológicos

4.1 - Avanços em Tecnologias Não-Invasivas

Capítulo 5 - Nasalidade 34

Capítulo 6 - Modelo Acústico 41

Capítulo 7 - Parâmetros Acústicos

Capítulo 8 - Programa "Análise de Voz 2.3" 50

Capítulo 9 - Material e Método 56

Capítulo 10 - Resultados

10.1 - Recurso “Comparação” 58

10.2 - Recurso "Analisador" 65

Capítulo 11 - Conclusão 72

Referências Bibliográficas 74 


\section{Introdução}

A voz humana possibilita a comunicação e a expressão de pensamentos. Através desta transmitimos todos os nossos sentimentos - tais como choro, riso, alegria e tristeza.

A voz é produzida pelas vibrações das pregas vocais ocasionadas pela passagem de ar advindo dos pulmões através do principal órgão fonatório: a laringe. Além do aparelho fonatório, é essencial para a fonação a participação dos sistemas respiratório e articulatório que serão discutidos no capítulo 1 . O primeiro é composto principalmente pelos pulmões fornecendo a corrente de ar necessária para vibrar as pregas vocais e o articulatório composto por lábios, dentes, língua, palato e seios paranasais que determina as freqüências formantes. Inicialmente, a voz é produzida pela vibração das pregas vocais, mas aqui apresenta uma qualidade pobre. É a partir das estruturas da faringe, da cavidade oral, da cavidade nasal e dos seios paranasais, atuando como ressonadores, que se molda a qualidade e amplifica a intensidade do som.

O mecanismo vocal será introduzido no capítulo 2 para definir os termos utilizados neste trabalho, a saber: freqüência fundamental (Fo), harmônicos, ressonância e formante vocálico.

Neste trabalho de mestrado, focalizamos a fala hipernasalada, ou seja, quando há um escape indesejado de ar pelo esfíncter velofaríngeo. No capítulo 3 será apresentada as estruturas velofaríngeas. $\mathrm{Na}$ fala normal, ou seja, quando existe equilíbrio entre as 
ressonâncias oral e nasal, ocorre um acoplamento adequado entre estas duas cavidades através de uma ação valvular denominada esfíncter velofaríngeo (EFV). Este é composto pelo palato mole e pelas paredes laterais e posterior da faringe. Essa ação valvular acontece quando o palato mole movimenta-se para cima e para trás ao concomitante à constrição das paredes laterais e posterior da faringe. Quando ocorre uma disfunção desta válvula há um acoplamento entre as cavidades oral e nasal permitindo que ondas indesejáveis passem pela cavidade nasal, e a fonação torna-se perceptivelmente hipernasal.

O capítulo 4 apresentará os instrumentos recentemente utilizados para avaliar a fala. A avaliação da nasalidade geralmente é feita através de análises subjetivas. As avaliações subjetivas ou perceptivo-auditivas são dependentes dos conceitos pessoais do avaliador a respeito de suas habilidades de percepção, de discriminação e de experiência. Também pode-se avaliar falas nasais objetivamente através da análise acústica. Usando programas computadorizados podemos estudar suas características acústicas, permitindo uma avaliação objetiva da voz. O uso de instrumentos é de grande valia para o diagnóstico e para o tratamento de indivíduos com problemas vocais, pois proporcionam dados objetivos e mensuráveis, auxiliando dessa forma na avaliação clínica.

No capítulo 5 será apresentado vários artigos na literatura referentes a nasalidade, sendo a maior parte destes baseados em dados objetivos.

O modelo acústico da fala introduzido no capítulo 6 exemplifica, de uma forma simplista, como é modelado o trato vocal humano.

O capítulo 7 cita vários parâmetros acústicos existentes para analisar a fala.

O programa utilizado neste trabalho será discutido em detalhes no capítulo 8 .

Material e método, bem como resultados e conclusão encontram-se, respectivamente, nos capítulos 9, 10 e 11. 


\section{Capítulo 1 - Anatomia dos Aparelhos: Respiratório, Fonatório e}

\section{Articulatório}

Para a produção da fonação é necessário que algumas estruturas do corpo humano trabalhem em conjunto. A fala é um ato complexo dependente da coordenação de três sistemas, a saber: sistema respiratório, sistema fonatório e sistema articulatório. Neste capítulo, iniciamos nossa discussão com uma introdução da anatomia do sistema respiratório. Em seguida, apresentamos brevemente a anatomia do aparelho fonatório e para finalizarmos este capítulo, comentamos o sistema articulatório. 


\section{Aparelho Respiratório}

\section{1 - Sistema Respiratório}

A respiração é uma das características básicas dos seres vivos. O sistema respiratório possibilita a entrada de ar necessitada pelo organismo. Essencialmente, consiste de absorção de oxigênio (na inspiração) e eliminação do gás carbônico (na expiração). Outra função, também realizada pelo sistema respiratório, é a vocalização. Torna-se possível falar, cantar e rir devido à variação da tensão das pregas vocais quando o ar exalado passa através delas (DÂGELO, 1997).

O sistema respiratório engloba o nariz externo, cavidade nasal, faringe, laringe, traquéia, brônquios, pulmões - vistos na figura 1 - e por um conjunto de músculos que permitem a entrada e saída de ar dos pulmões - vistos na figura 2.

As funções do nariz e das cavidades nasais são as de respiração, olfação, filtração de poeira, umidificação do ar inspirado e recepção de secreções dos seios paranasais e dos ductos nasolacrimais.

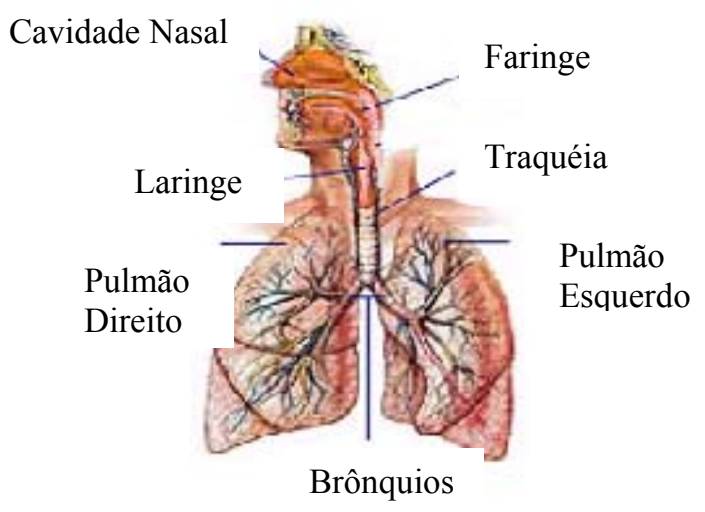

Figura 1 - Estruturas que compõe o aparelho respiratório

Fonte: http://www.corpohumano.hpg.ig.com.br/respiracao/respiracao2.html, acessado em25/11/2002 


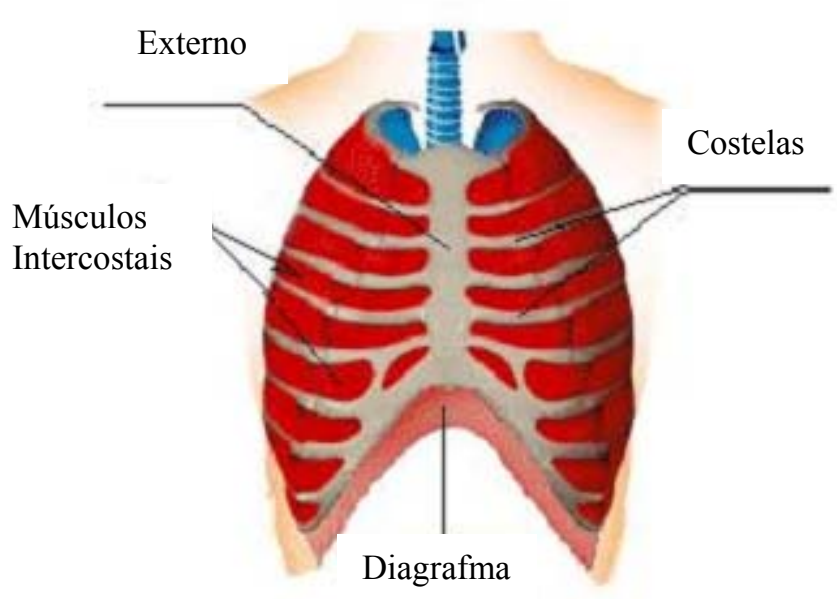

Figura 2 - Conjunto de músculos associados com a respiração

Fonte: http://www.terravista.pt/Copacabana/1519/respirat\%F3rio/pulmoes.htm, acessado em $25 / 11 / 2002$

$\mathrm{O}$ ar entra pelo nariz passando pela traquéia caminhando em direção aos pulmões. A traquéia termina em duas bifurcações denominados brônquios. Ao penetrarem nos pulmões estes se dividem em brônquios menores, que por sua vez dividem num grande número de bronquíolos menores ainda. Os bronquíolos dividem-se em ductos alveolares, que contém alvéolos (sacos alveolares) na forma de cachos.

Os pulmões são órgãos pares, esponjosos e muito elásticos especializados na troca de gases entre o ar atmosférico e o sangue (House e Stevens, 1956). Têm aproximadamente $25 \mathrm{~cm}$ de comprimento e pesa cerca de 700 gramas. O pulmão direito é ligeiramente maior do que o esquerdo. Estão envolvidos pela pleura, uma fina membrana que se dobra sobre si formando uma dupla camada ao redor de cada pulmão. A pleura interna está ligada ao pulmão e a externa à caixa torácica. Esta caixa é formada, em cada lado, por doze costelas fixas e dentro dela encontram-se os pulmões. Os pulmões estão limitados lateralmente e superiormente pelas costelas e o externo, e ainda, inferiormente por uma membrana de 
tecido muscular denominada diafragma. Seus movimentos de contração e relaxamento são importantes para o processo de respiração.

A respiração consiste na troca gasosa efetuada entre o nosso corpo e o meio ambiente. Para tal, é necessário a realização do movimento de inspiração e de expiração.

$\mathrm{Na}$ inspiração, o ar entra pelas narinas, sendo conduzido para a laringe, traquéia e alvéolos, onde a troca gasosa com o sangue será efetuada. Para que a inspiração aconteça, o diafragma terá que se contrair e descer e os pulmões dilatam-se. O diafragma é o músculo mais importante na respiração. A musculatura situada no pescoço e os músculos intercostais (visto na figura 2) localizados na região das costelas são responsáveis pela expansão da caixa torácica, e também ajudam na entrada do ar (GUYTON, 1988).

A expiração corresponde à saída de ar dos pulmões. Os músculos abdominais auxiliam na saída do ar que já foi utilizado pelo corpo. Aqui o diafragma relaxa e, conseqüentemente sobe, fazendo com que os pulmões possam se contrair.

Nestes dois movimentos resultantes da respiração, as pregas vocais permanecem em posição de repouso, ou seja, ficam abertas (abduzidas).

A fonação só ocorre na fase de expiração, quando as pregas vocais encontram-se na posição fechada (aduzidas). A figura 3 mostra a posição das pregas vocais durante a fonação e durante a respiração.

A produção da fala se inicia no final da inspiração quando as pregas vocais fechamse aprisionando o ar no trato respiratório inferior (subglotal). Quando se inicia a exalação, a caixa torácica desce e o diafragma move-se para cima, causando um aumento de pressão subglótica. Enquanto a pressão abaixo da glote é formada, as pregas vocais começam a se separar soltando um "trem" de ar. Quando o ar passa pelo estreito espaço glótico, ocorre uma pressão negativa fazendo com que as pregas vocais fechem-se novamente. Esse 
processo é repetido aproximadamente 100 vezes por segundo em um homem e 200 vezes por segundo em uma mulher. Essa razão de vibração das pregas vocais determina a freqüência fundamental.
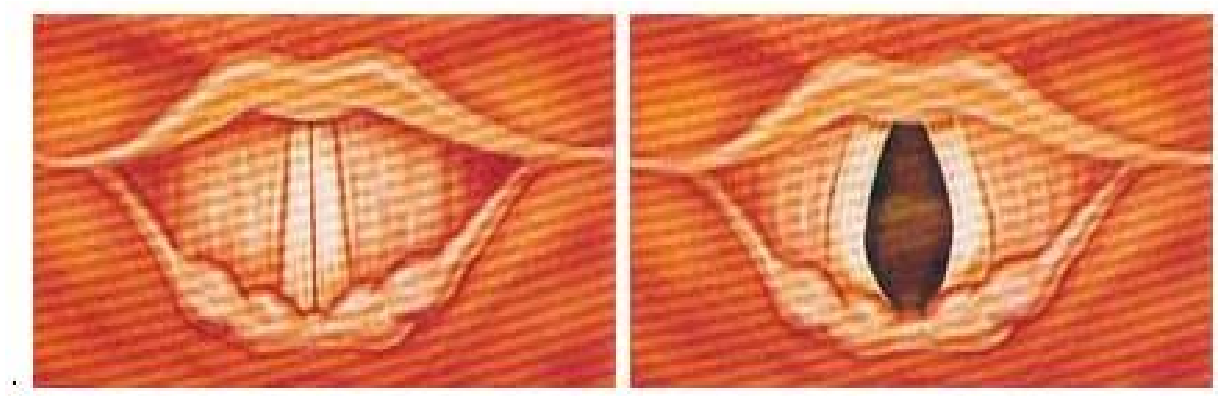

Figura 3 - Na figura à esquerda as pregas vocais encontram-se aduzidas. Elas se aproximam e vibram para produzir a fala. Na figura à direita as pregas vocais estão abduzidas para a respiração Fonte: http://www.uol.com.br/cienciahoje/chc/chc112b2.jpg, acessado em 25/11//2002

\subsection{1 - Anatomia Nasal e Cavidade Nasal}

O nariz é uma protuberância situada no centro da face, sendo que sua parte exterior é denominada de nariz externo e a parte interior de cavidade nasal.

A parte externa do nariz é composta por uma estrutura ósteo-cartilagínea, ou seja, possui ossos nasais - porções das duas maxilas - e diversas cartilagens. O nariz pode ser comparado a uma pirâmide triangular, cuja extremidade superior é denominado raiz e a extremidade inferior recebe o nome de base. Nesta, encontram-se duas aberturas denominadas narinas que estão separadas pelo septo nasal. O ponto mais projetado da base do nariz chama-se ápice. A extensão correspondente entre a raiz e o ápice é denominada 
dorso do nariz, e é este que proporciona a forma do nariz, podendo ser retilínio, côncavo ou convexo (SPENCE, 1991).

O septo nasal divide o nariz em duas cavidades estreitas e é composto de estruturas tanto ósseas como cartilaginosas. Possui três componentes principais: a lâmina perpendicular do osso etmóide; o vômer e a cartilagem do septo nasal.

A lâmina perpendicular, que forma a parte superior do septo, é muito fina e desce a partir da lâmina crivosa do osso etmóide. O vômer, um osso fino e plano, forma a parte póstero-inferior do septo.

A cavidade nasal estende-se ântero-posteriromente das narinas até as coanas. Pode ser dividida em vestíbulo, região respiratória e região olfatória. $\mathrm{O}$ ar que passa na região respiratória é aquecido e umedecido antes de atravessar o restante da via respiratória superior até os pulmões.

O vestíbulo é a primeira parte da cavidade nasal, cuja parte inferior está coberta por pele e provida de pêlos denominado vibrissas. Esses pêlos impedem a entrada de maiores partículas inspiradas pelas narinas (DÂNGELO, 1997 e HOLLINSHEAD, 1991).

A parede medial, formada pelo septo nasal, geralmente é lisa. As paredes laterais da cavidade nasal são irregulares devido a três elevações longitudinais, denominadas conchas (também chamados de cornetos ou turbinados). Essas conchas são lâminas curvadas de ossos cobertas por mucosa e são denominadas de concha nasal superior, média e inferior, tendo essa denominação de acordo com sua posição na parede lateral da cavidade nasal. As conchas superior e média são partes do osso etmóide, ao passo que a concha inferior é um osso distinto. Os espaços para a passagem de ar situado por dentro das conchas são conhecidos como meatos nasais inferior, médio e superior, visualizados na figura 4 . $\mathrm{O}$ 
espaço póstero-superior à concha superior e no qual o seio esfenoidal se abre é denominado recesso esfenoetmoidal (LEESON, 1970).

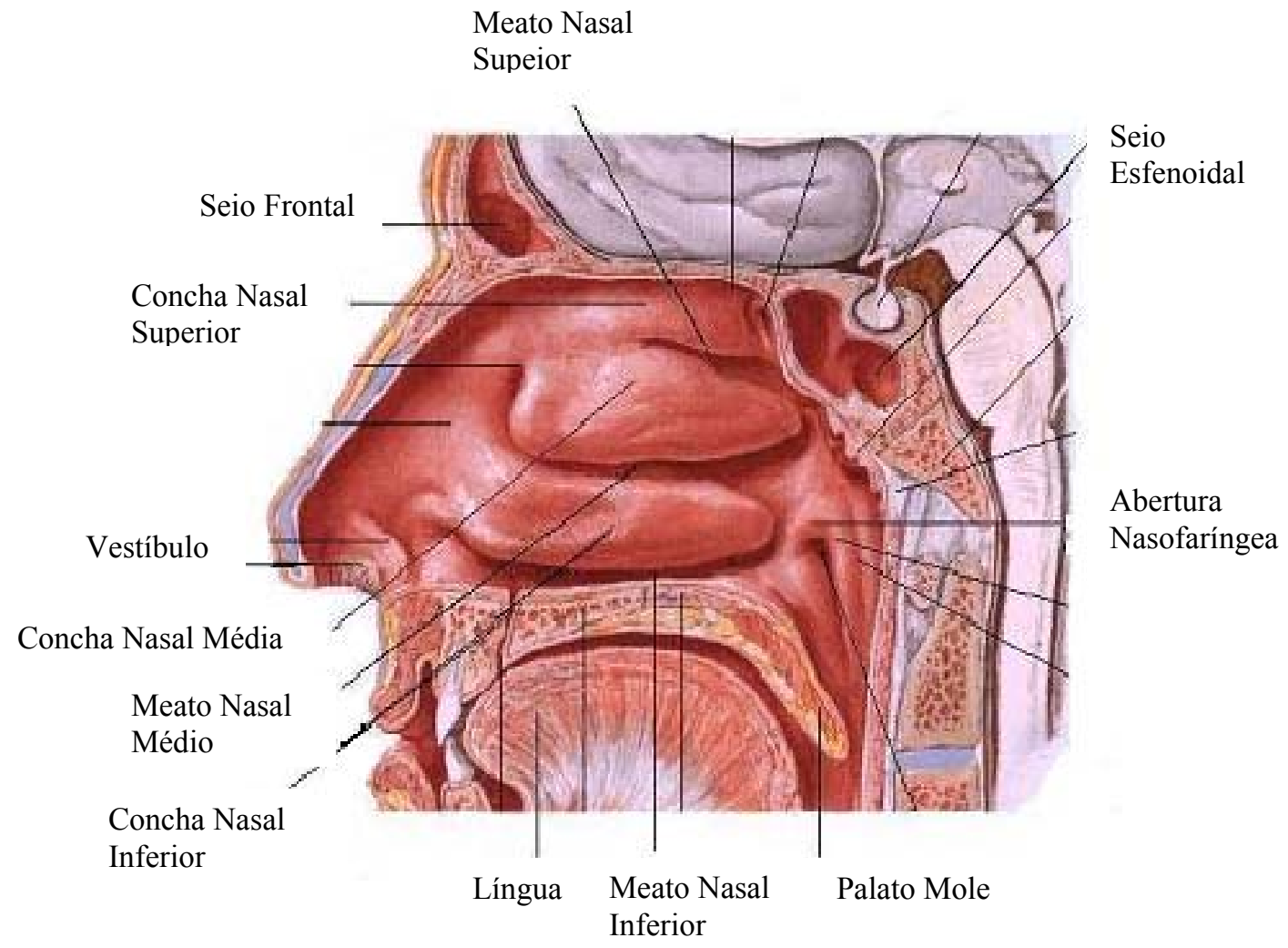

Figura 4 - Visualização das conchas nasais e seus respectivos meatos nasais

Fonte: NETTER, Frank H.. Atlas de Anatomia Humana. 2ed. Porto Alegre: Artmed, 2000

O teto da cavidade nasal é formado pela lâmina crivosa do osso etmóide e o assoalho formado pelo palato duro (ósseo) e mais posteriormente pelo palato mole (muscular). O palato separa a cavidade nasal da cavidade bucal, como podemos observar na figura 5. A cavidade nasal abre-se posteriormente na nasofaringe (parte nasal da faringe) através das coanas. 


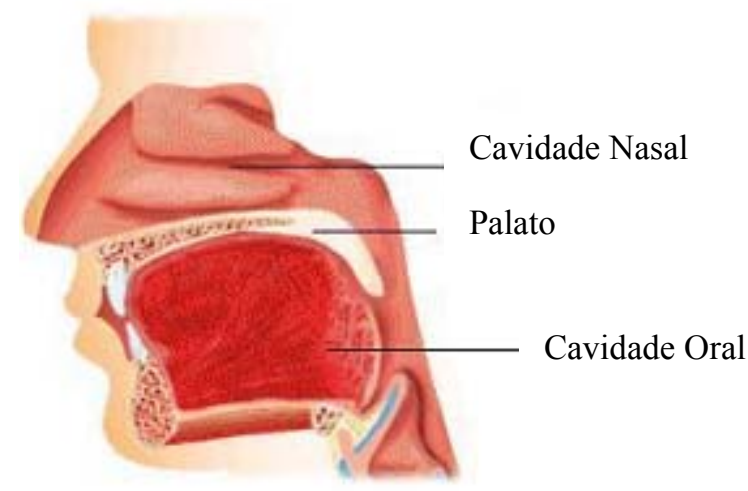

Figura 5 - Podemos observar as cavidades oral e nasal separadas pelo palato

Fonte: http://www.anatomiaonline.hpg.ig.com.br/respiratorio.htm, acessado em 25/11/2002

\subsection{2 - Seios Paranasais}

Os seios paranasais são cavidades encontradas no interior dos ossos da maxila, do frontal, do esfenóide e do etmóide. Variam muito em tamanho e forma de um indivíduo para outro. A maior parte dos seios da face são rudimentares ao nascimento; eles aumentam apreciavelmente de tamanho durante a erupção dos dentes permanentes e após a puberdade, alterando o tamanho e a forma da face (SPENCE, 1991).

De acordo com a região que encontra-se, recebe o nome de seio maxilar, seio frontal, seio esfenoidal e seio etmoidal. Fazem parte da porção respiratória e estão cheios de ar. Estes ossos estão representados na figura 6. 


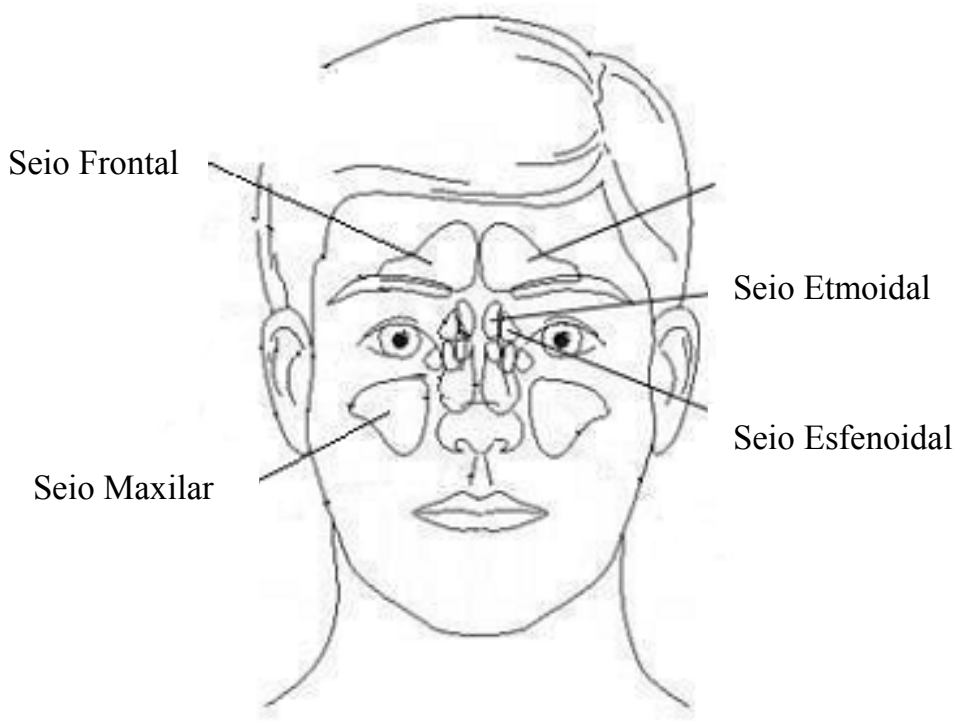

Figura 6 - Ossos da face: seio frontal, seio maxilar, seio etmoidal e seio esfenoidal

Fonte: http://www.anatomiaonline.hpg.ig.com.br/respiratorio.htm, acessado em 25/11/2002

O maior seio paranasal é o seio maxilar, tendo em média uma capacidade de $15 \mathrm{ml}$. Encontra-se na proeminência da bochecha, onde seu teto, parede lateral e assoalho são compostos da maxila.

Situado no osso frontal, temos o seio frontal. É o segundo maior seio da face com capacidade de $4 \mathrm{ml}$ a $8 \mathrm{ml}$. Possui formas e tamanhos variados - tanto que é utilizado em deontologia para identificação de pessoas.

O seio esfenoidal é o mais posterior da cavidade nasal, localizado no interior do corpo do osso esfenóide e possui uma capacidade total de $4 \mathrm{ml}$ a $5 \mathrm{ml}$.

E por fim, o seio etmoidal é constituído por pequenas cavidades, denominadas células etmoidais, cujo número de células variam de três a dezoito em cada lado. Sua capacidade total é da ordem de 2ml a 3ml (CASTRO, 199? e HOLLINSHEAD, 1991). 


\section{Aparelho Fonatório}

\section{2 - Sistema Fonatório}

O sistema fonatório é composto pela laringe e pregas vocais, sendo estas localizadas no interior da laringe. Quando inspiramos, o ar move-se em direção à laringe caminhando-se para a traquéia.

A laringe é um órgão localizado logo acima da traquéia. É composta por cartilagens, músculos, ligamentos, artérias, veias e nervos. Suas principais funções são as de impedir que corpos estranhos - tais como alimentos e salivas - entrem na via aérea indo direto para os pulmões e a de produzir som (HUCHE, 1999).

\subsection{1 - Anatomia da Laringe}

A laringe conecta a laringofaringe (parte laríngea da faringe) com a traquéia. $\mathrm{O}$ ar que vai para os pulmões ou o ar que vem deles passa por ela. Existe uma mucosa perto da entrada da laringe, que forma dois pares de pregas horizontais e se estendem uma de cada lado desde a cartilagem tireóide até a cartilagem aritenóide.

O par superior de pregas recebe o nome de pregas vestibulares, também conhecidas como falsas pregas vocais. O par inferior é denominado pregas vocais ou pregas vocais verdadeiras. A abertura entre as pregas vocais é chamada de glote, e através deste, o ar entra na laringe. Estas estruturas podem ser vistas na figura 7 (SPENCE, 1991). 


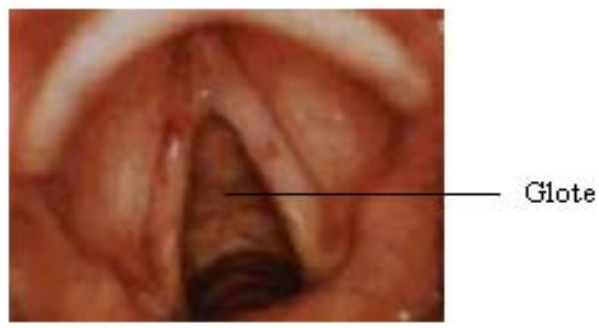

Figura 7 - Visualização das pregas vocais e da glote

Fonte: www.alfinal.com/orl/laringenormal.jpg , acessado em 29/11/2002

Nas pregas vocais existem ligamentos elásticos que fazem conexão com as cartilagens tireóide, cricóide e aritenóide.

\subsection{2 - Cartilagens e Músculos}

As cinco principais cartilagens da laringe são: cricóide, tireóide, um par de aritenóides e epiglote. Estas principais cartilagens podem ser vistas nas figuras 8, 9, $10 \mathrm{e}$ 11. Existem outros dois pares de cartilagens que exercem função mínima na fonação chamadas de corniculares e cuneiformes. As figuras 8 e 9 mostram a traquéia, o osso hióide e seus ligamentos (BOONE, 1994 e HUCHE, 1999).

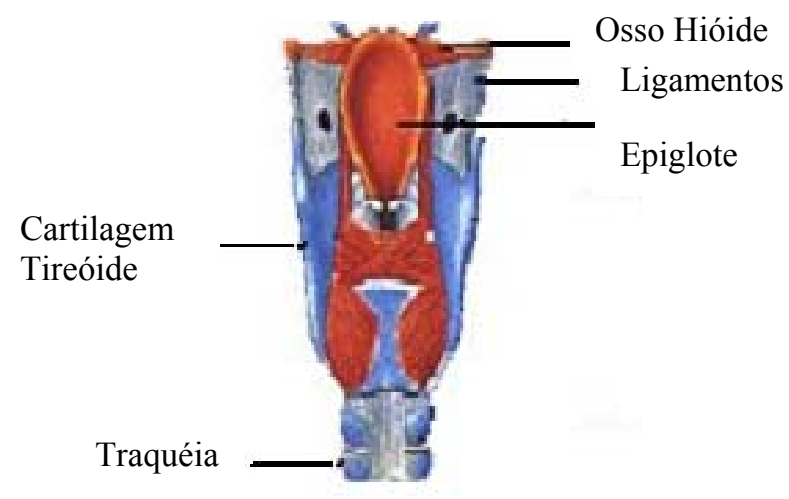

Figura 8 - Cartilagens da laringe vistas posteriormente

Fonte: : www.corpohumano.hpg.ig.com.br/ .../laringe/laringe2.html, acessado em 29/11/2002 


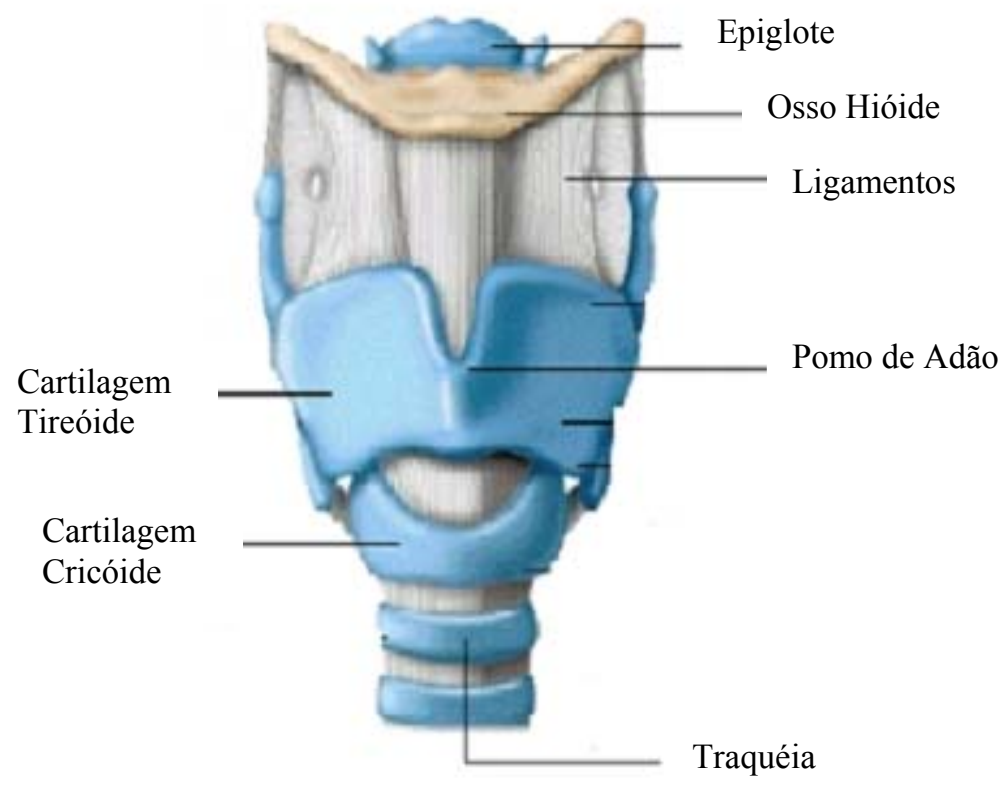

Figura 9 - Cartilagens da laringe vistas de frente

Fonte: www.webciencia.com/ 11_08laringe.jpg, acessado em 29/11/2002

A cricóide localiza-se na base da laringe sustentando às demais cartilagens. Seu formato é circular, cuja parte posterior é chamada de engaste cricóideo ou lâmina da cartilgem cricóide e sua porção anterior constitui o arco cricóideo. Na parte anterior desse arco encontra-se uma pequena saliência chamada tubérculo cricóideo.

A cartilagem tireóide apresenta-se na forma da letra maiúscula U. Basicamente, é formada por duas lâminas quadriláteras e por cornos inferiores e cornos superiores. Envolve, parcialmente, a cricóide e as aritenóides e ainda articula-se com a primeira cartilagem através dos cornos inferiores.

As aritenóides são cartilagens pares e simétricas em forma de pirâmide triangular. Cada pirâmide é composta por três faces, uma interna, uma posterior e uma anterior. Essa última apresenta em sua porção inferior uma depressão chamada fosseta hemisférica, em 
que se insere a prega vocal. As aritenóides desempenham um papel fisiológico fundamental, pois têm a capacidade de estirar ou relaxar a musculatura das pregas vocais.
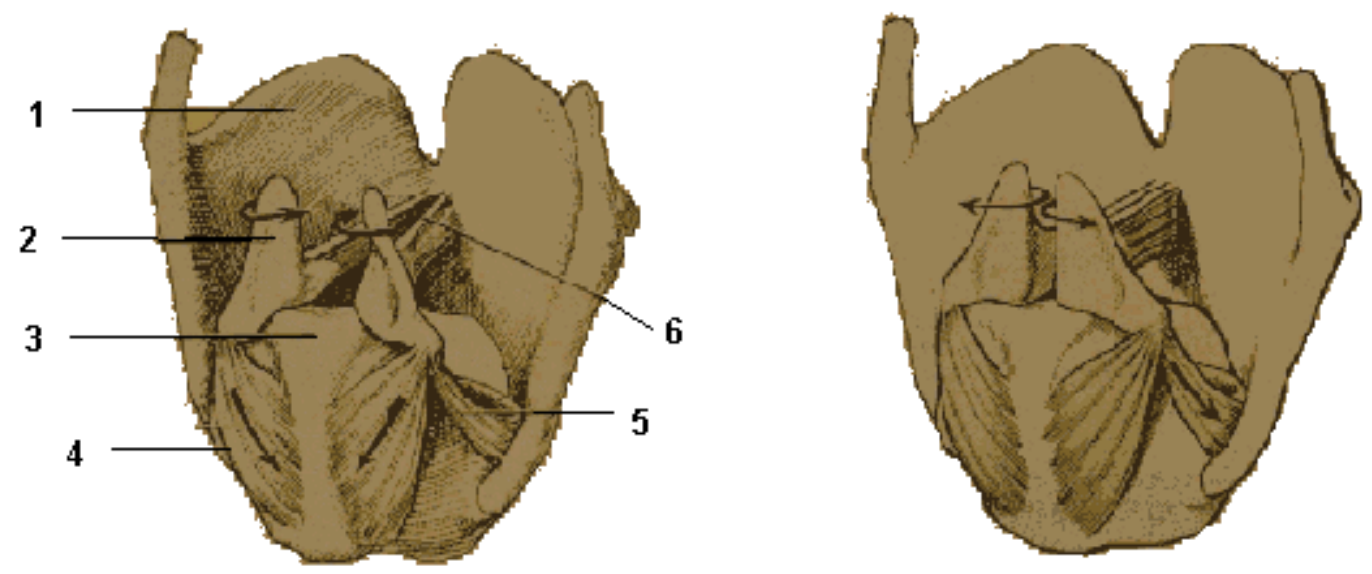

Figura 10 - Visualização da cartilagem aritenóide. 1- Cartilagem Tireóide; 2- Cartilagens Aritenóides; 3- Cartilagem Cricóide; 4- Músculo Cricoaritenóide Posterior (sua contração abre as pregas vocais - na respiração); 5- Músculo Cricoaritenóide Lateral (sua contração aproxima as pregas vocais - na vocalização); 6- Pregas Vocais

Fonte: http://www.centreorl.net/multimedia/pictures/imagenes/t3f3.gif, acessado em 05/12/2002

A epiglote é uma cartilagem delgada e flexível apresentada na forma de uma pétala. Localiza-se na parte superior da laringe. Sua ponta inferior prende-se ao ângulo interno da cartilagem tireóide através do ligamento tireoepiglótico. Possui duas funções, a primeira é tapar a laringe, durante a deglutição, de maneira que os alimentos não entrem nos pulmões e a segunda é abrir a passagem de ar na respiração e na fonação (ERHART, 1995 e HUCHE, 1999). 


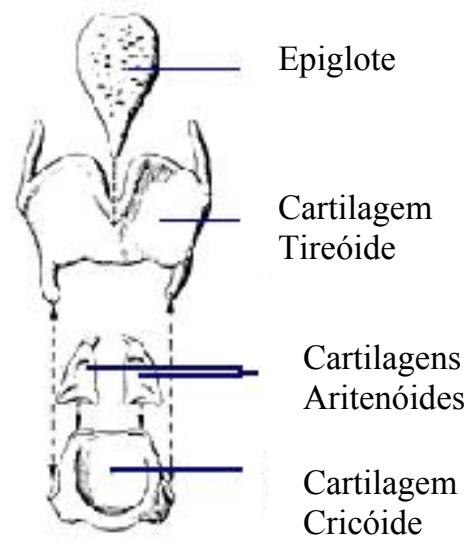

Figura 11 - Cartilagens laríngeas: epiglote, tireóide, aritenóides e cricóide

Fonte: www.latinsalud.com/ Temas/voz.htm, acessado em 05/12/2002

Além das cartilagens, a laringe também possui dois tipos de músculos, os intrínsecos e os extrínsecos. Essa nomenclatura está relacionada com a posição no sistema de vocalização. Os músculos intrínsecos, ou seja, músculos internos da laringe, são cricotireóideos, cricoaritenóideos posteriores e laterais, tireoaritenóideo superior e inferior. Esses músculos agem diretamente sobre a fonação.

A função dos cricotireóideos é tensionar as pregas vocais, fechando-as. Esses músculos são inervados pelo nervo laríngeo externo, ramo do nervo laríngeo superior. Não apresenta feixes neuromusculares, no que implica ser um músculo mais voluntário que os demais músculos da laringe.

Os cricoaritenóideos posteriores são os únicos músculos dilatadores da glote. Ao contraírem-se afastam as cartilagens aritenóides fazendo assim com que as pregas vocais relaxem (como podemos observar na figura 10). Já os cricoaritenóideos laterais possuem função oposta, pois atraem essas cartilagens, umas às outras, produzindo a adução das 
pregas vocais (também mostradas na figura 10). Ambos são inervados pelo ramo anterior do nervo recorrente.

O músculo tireoaritenóideo superior é um músculo constritor da glote. Também é inervado pelo ramo anterior do nervo recorrente. Já o tireoaritenóideo inferior tem principalmente função de ser um constritor da glote, e secundariamente função fonatória. É o músculo que está mais diretamente implicado na produção vocal. Também é inervado pelo ramo anterior do nervo recorrente (BOONE, 1994 e HUCHE, 1999).

Os músculos extrínsecos, ou seja, músculos externos da laringe, proporcionam apoio fixo para a laringe e tanto podem elevar quanto abaixar sua posição no pescoço e são denominados de músculos elevadores e músculos depressores, respectivamente. Os músculos elevadores são formados pelos digástricos, genio-hióideos, milo-hióideos e estilohióideos. Esses músculos elevam a laringe, durante a deglutição e, levemente, durante a produção de notas agudas cantadas. E os músculos depressores são constituídos pelos omohióideos, esterno-hióideos, esterno-tiróideos e tiro-hióideos. Esses músculos abaixam a laringe depois da deglutição e após ter cantado notas agudas, e também abaixam um pouco para o canto de notas graves.

Além dessas duas classificações dos músculos externos, temos também o músculo cricofaríngeo (também externo), cuja função está relacionada com a fixação da laringe e de permitir a produção de fala esofágica, quando o indivíduo é adequadamente treinado.

\subsection{3 - Osso Hióide}

É de grande importância citarmos o osso hióide, pois nele se insere a maior parte dos músculos extrínsecos discutidos acima. O osso hióide é um semicírculo ósseo com a 
concavidade voltada para trás e localiza-se acima da cartilagem tireóide, à qual se vincula através de ligamentos. Divide-se em três partes, sendo estas o corpo (lâmina óssea quadrilátera e achatada no sentido ântero-posterior), os cornos maiores (suas terminações são protuberâncias chamadas de tubérculos dos cornos maiores) e os cornos menores (pequenas saliências ósseas com origem na união dos bordos superiores do corpo e do corno maior).

Estas estruturas do osso hióide estão representados na figura 12 (HUCHE e ALLALI, 1999).

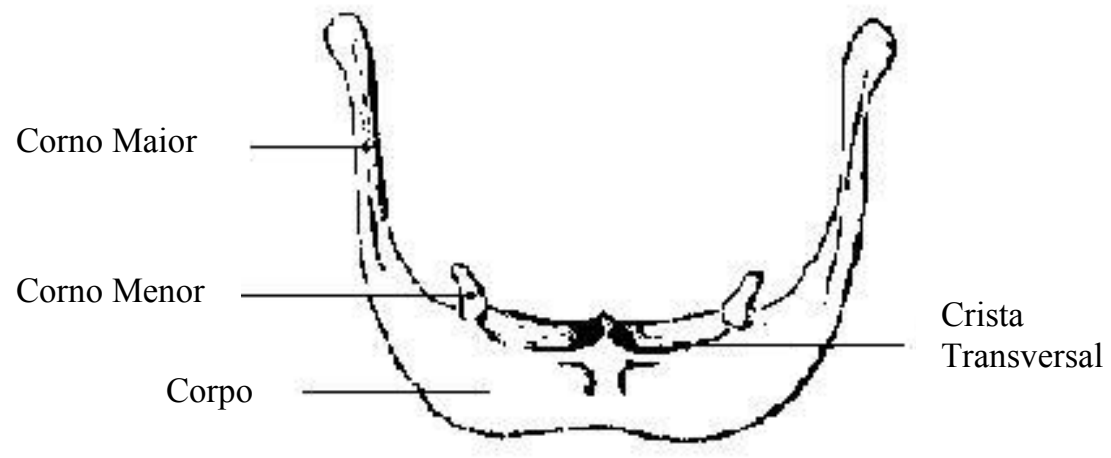

Figura 12 - Vista frontal do osso hióide

Fonte: Huche, F. L. e Allali, A., 1999

\section{Aparelho Articulatório}

\section{3 - Sistema Articulatório}

A articulação é criada pela variação no tamanho e na forma do trato vocal, o que ocorre através do movimento de muitas estruturas tais como: lábios; dentes; língua, palato duro e palato mole. 
A cavidade oral, também denominada cavidade bucal, é constituída pelas bochechas, palato mole, palato duro e língua.

As bochechas formam as paredes laterais da face e são constituídas externamente por pele e internamente por mucosa. O palato duro está localizado na parede superior da boca e o palato mole localiza-se na parede posterior.

A língua é um órgão muscular multifuncional localizado na parte interna da boca e tem como funções: gustação, fonação, deglutição e atua como um importante articulador. Ela altera o tamanho e a forma das cavidades oral e faríngea. Podemos visualizar todas estas estruturas na figura 13.

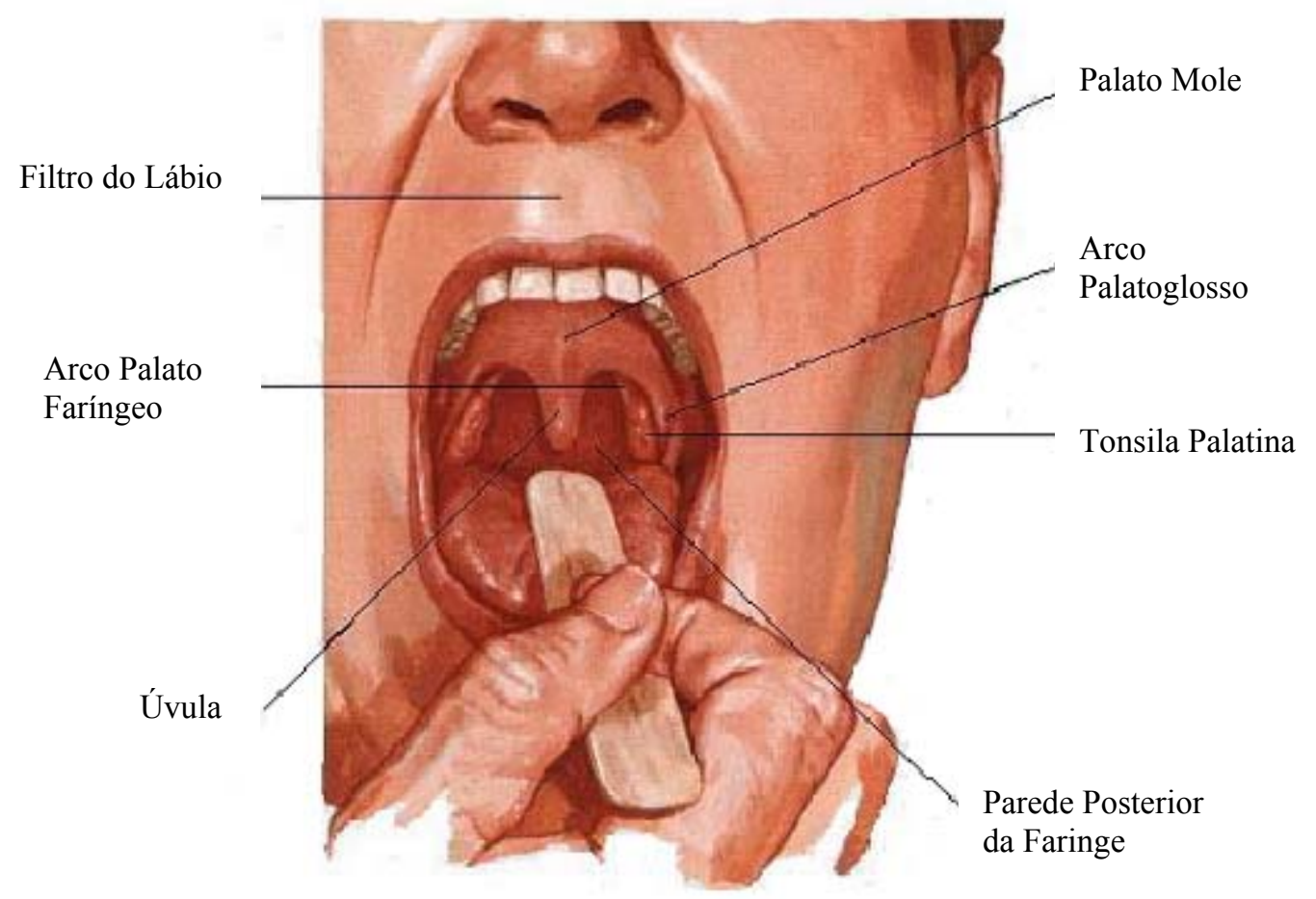

Figura 13 - Visualização dos articuladores: lábio supeior e inferior, dentes, língua e palato mole Fonte: Netter, F. H.. Atlas de Anatomia Humana. 2ed. Porto Alegre: Artmed, 2000 
Podemos observar na figura 14 a região onde localizam-se os palatos mole e duro. Também são considerados como articuladores, pois seu formato varia de pessoa para pessoa interferindo, desta forma, na fonação.
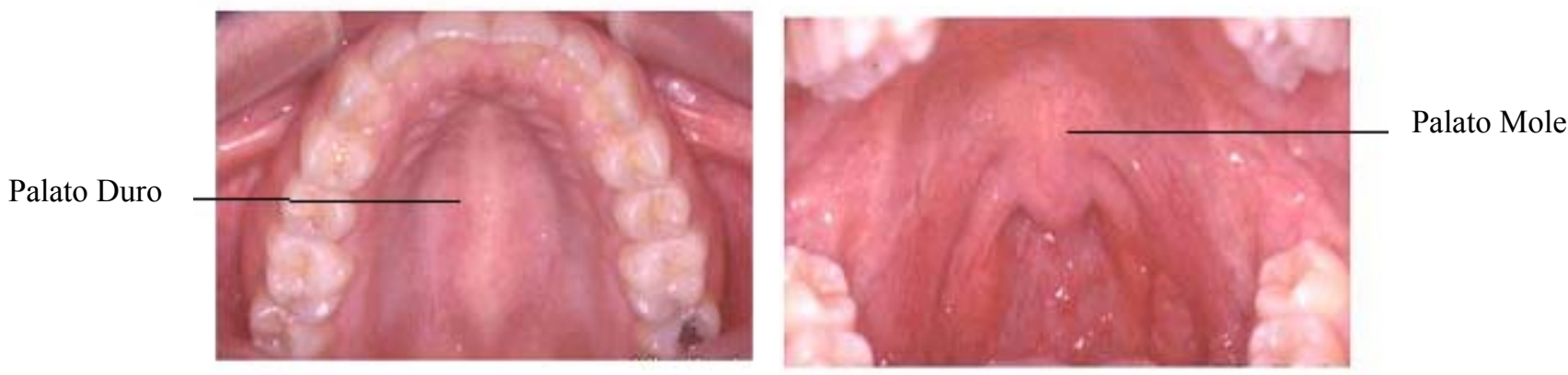

Figura 14 - À esquerda vemos o palato duro e à direita o palato mole

Fonte: www.alfinal.com/orl/laringenormal.jpg, acessado em 30/01/2003

No interior da cavidade bucal encontram-se os dentes - órgãos mineralizados, resistentes e esbranquiçados. Desempenham importante papel na mastigação, na estética da face e também atuam como articuladores. Estão dispostos em duas fileiras denominadas arcadas dentárias como podemos observar na figura 15.

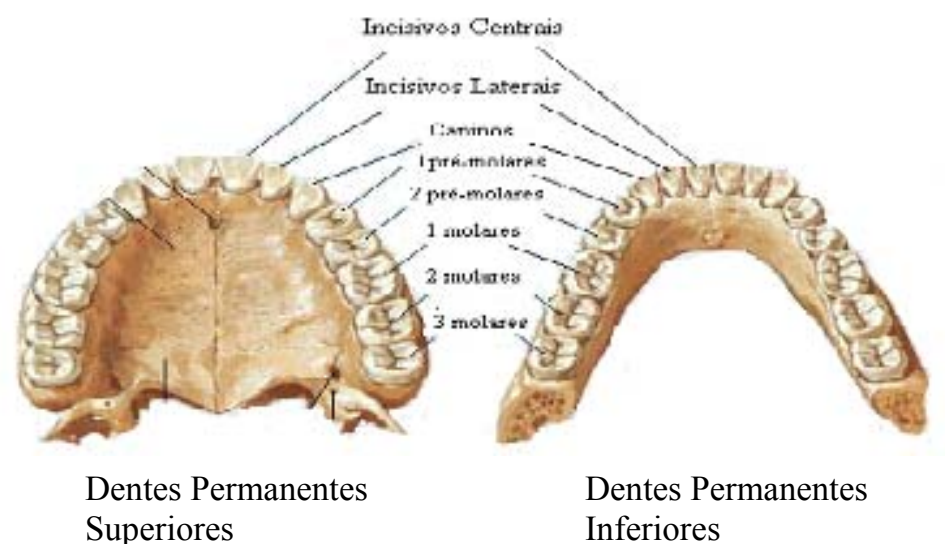

Figura 15 - Arcada dentária

Fonte: Netter, F. H.. Atlas de Anatomia Humana. 2ed. Porto Alegre: Artmed, 2000 


\section{Capítulo 2 - Mecanismo Vocal}

O mecanismo vocal envolve os pulmões e o diafragma como fontes de energia; a laringe como gerador da excitação; a faringe, boca e nariz (trato nasal) como um sistema ressonador.

Será abordado neste capítulo uma breve discussão sobre os temas freqüência fundamental, ressonância e formantes. 


\section{1 - Frequência Fundamental, Harmônicos e Ressonância}

Freqüência fundamental $(\mathrm{Fo})$ corresponde à freqüência do sinal excitatório proveniente da glote, ou seja, é o número de vibrações das pregas vocais por segundo. A freqüência fundamental também recebe o nome de primeiro harmônico. Para os homens a freqüência fundamental varia em torno de $113 \mathrm{~Hz}$, para mulheres em torno de $220 \mathrm{~Hz}$ e para crianças $240 \mathrm{~Hz}$. Os fatores físicos que regulam a freqüência de vibração são a massa, o comprimento e a tensão das pregas vocais, todos controlados pelos músculos intrínsecos e extrínsecos da laringe.

Quanto mais rápido as pregas vocais vibrarem, mais alta é a freqüência percebida da voz. Nesta situação, as pregas estão mais alongadas e tensas. Por outro lado, quanto menor a vibração mais baixa é a freqüência percebida da voz, e as pregas vocais estão mais encurtadas.

Quando o fluxo de ar, proveniente dos pulmões, move-se superiormente à glote, este é ressoado pela laringe, faringe, cavidade oral e cavidade nasal. Esta ressonância realça componentes de freqüências adicionais chamados harmônicos. Harmônico é definido como um conjunto de números inteiros múltiplos da freqüência fundamental. Por exemplo, uma onda sonora possui uma freqüência fundamental de $200 \mathrm{~Hz}$, então os componentes com 400 e 600 Hz são seus harmônicos, usualmente são chamados de segundo e terceiro harmônicos respectivamente (LADEFOGED, 1974 e ANDREASSEN, 1991).

O trato vocal atua como um ressonador com frequências que podem ser moduladas pelos articuladores, estabelecendo os formantes vocais, os quais tornam os sons de vogais reconhecíveis. 
O papel dos ressonadores é amplificar e modificar as ondas acústicas iniciadas nas pregas vocais.

O som é amplificado através das cavidades de ressonância, formadas pela faringe, cavidade oral e cavidade nasal. Depois, é modificado pelos dentes, lábios, língua e palato mole (parte posterior do céu da boca) resultando na fonação.

O tamanho da laringe, assim como o tamanho e o volume das cavidades de ressonância, interferem na característica sonora. Por esta razão, distinguimos os tipos de vozes que ouvimos no nosso cotidiano.

A mudança constante na forma, na posição e no grau de elasticidade das estruturas do trato vocal permite combinações acústicas variadas, ou seja, diferentes ressonâncias, o que resulta na imensa variedade de sons de fala que somos capazes de produzir.

Portanto, o sistema de ressonância é o responsável pela estética de uma voz, embelezando-a ou não.

\section{2 - Formante Vocálico}

O termo formante refere-se aos picos do espectro de uma vogal. Os formantes são muito importantes por serem componentes essenciais da fala. A distinção das vogais pode ser atribuída a diferenças em seus três primeiros formantes (vogais diferentes possuem formantes diferentes).

O posicionamento da língua é fundamental na produção de uma vogal, entretanto as posições da mandíbula e dos lábios também são importantes. Podemos observar estas 
características na figura 16, onde são mostradas as articulações do trato vocal para produção das vogais /a/ e /i/.

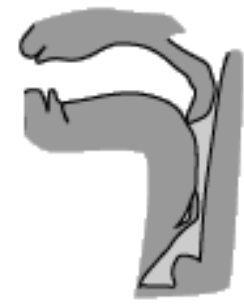

i

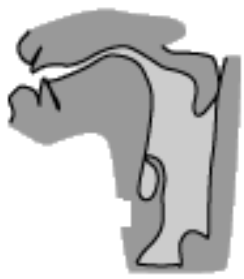

Figura 16 - Posicionamento do trato vocal para produzir uma vogal. Note as diferenças no posicionamento do trato vocal para produzi-las

Fonte: http://hyperphysics.phy-astr.gsu.edu/hbase/hframe.html, acessado em 05/12/2002

Os articuladores - movimento da língua, faringe, palato, mandíbula e lábios mostrados na figura 17 - são importantes na produção da fala, pois o processo de articulação determina as freqüências dos formantes e estes, então, são modificados pela cavidade ressoadora do trato vocal. O tamanho das cavidades ressonantes do trato vocal varia de acordo com o sexo e a idade, o que implica em uma variação na freqüência dos formantes, mais graves para adultos do sexo masculino e mais agudas para crianças.

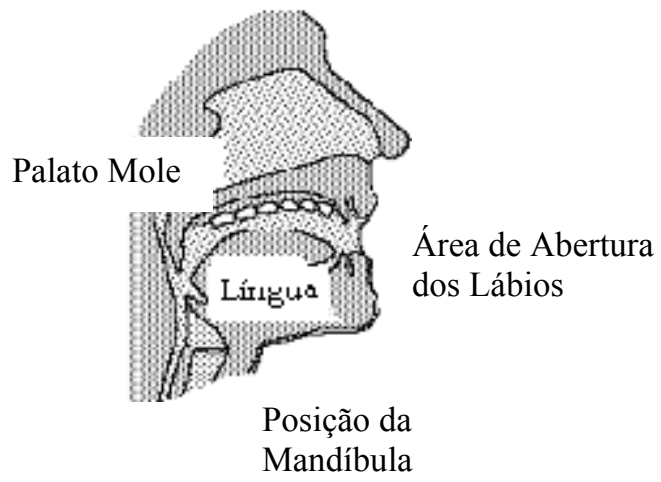

Figura 17- Estruturas importantes que determinam a freqüência dos formantes

Fonte: http://hyperphysics.phy-astr.gsu.edu/hbase/hframe.html, acessado em 05/12/2002 
A maior parte dos fonemas são ressoados nas cavidades faríngea e oral, mas os fonemas nasais, tais como: $/ \mathrm{m} /, / \mathrm{n} /, / \tilde{a} /$ e outros, além de serem ressoados por estas cavidades também serão ressoadas na cavidade nasal.

A figura 18 exibe o espectro vocal. À esquerda, vemos as diferentes configurações ao produzir diferentes vogais e à direita estão seus respectivos espectros vocálicos.

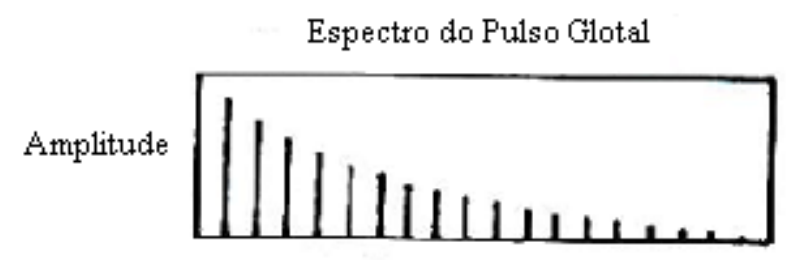

Freqüûtncia

Configuração do Trato Vocal
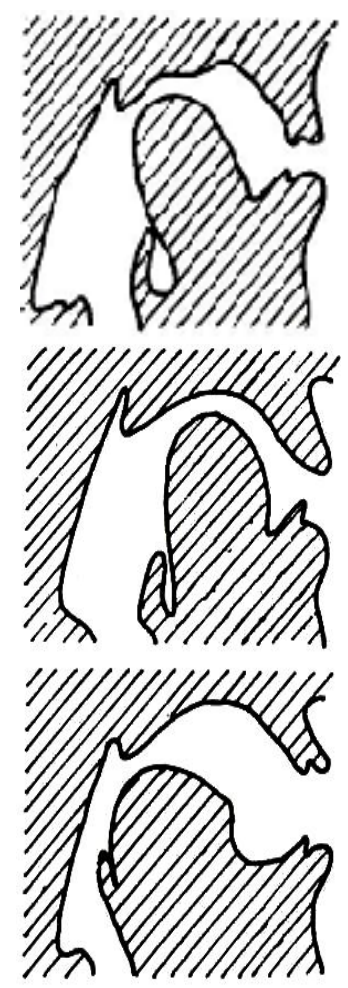

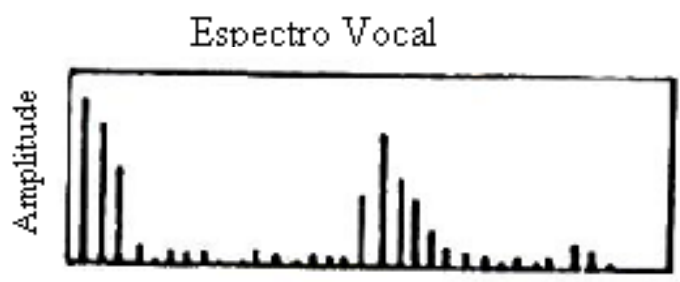

Frequuência

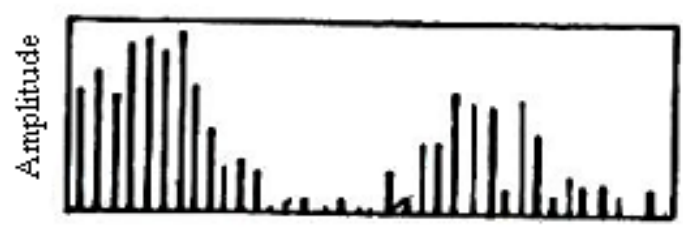

Freqüuência

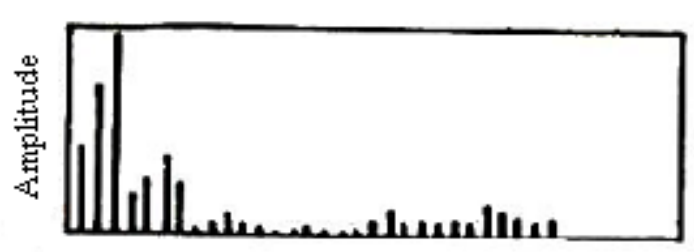

Freqüência

Figura 18 - À esquerda vemos as configurações do trato vocal e à direita seus respectivos espectros vocálicos

Fonte: Curtis, 1969 


\section{Capítulo 3 - Estruturas Velofaríngeas}

As estruturas que formam o esfíncter velofaríngeo (EFV) são as paredes laterais e posterior da faringe e o véu palatino. Para que a ressonância seja perceptivamente normal durante a fala, é preciso que esta estrutura cesse a conexão da cavidade oral com a cavidade nasal na produção de vogais e consoantes orais. Quando existe um acoplamento indesejável entre as cavidades oral e nasal a fala torna-se hipernasalizada. 


\section{1 - Esfíncter Velofaríngeo}

Algumas características vocais anormais podem estar relacionadas com a disfunção velofaríngea. Esta disfunção ocorre quando, por alguma razão, não há uma separação entre a cavidade oral e a cavidade nasal, ocorrendo desta forma, um escape indesejável de ar e de ondas acústicas pelo nariz tornando a fala com predomínio de ressonância hipernasal (SHPRINTZEN, 1995).

O esfíncter velofaríngeo (E.V.F.) corresponde à porção posterior da cavidade oral, entre a orofaringe e nasofaringe. Está delimitado anteriormente pelo palato mole e posteriormente pela parede posterior da faringe como mostra a figura 19. A separação entre as cavidades orais e nasais ocorre quando o palato mole move-se para cima e para trás em conjunto com a mesialização das paredes laterais e póstero-anteriorização da parede posterior da faringe.

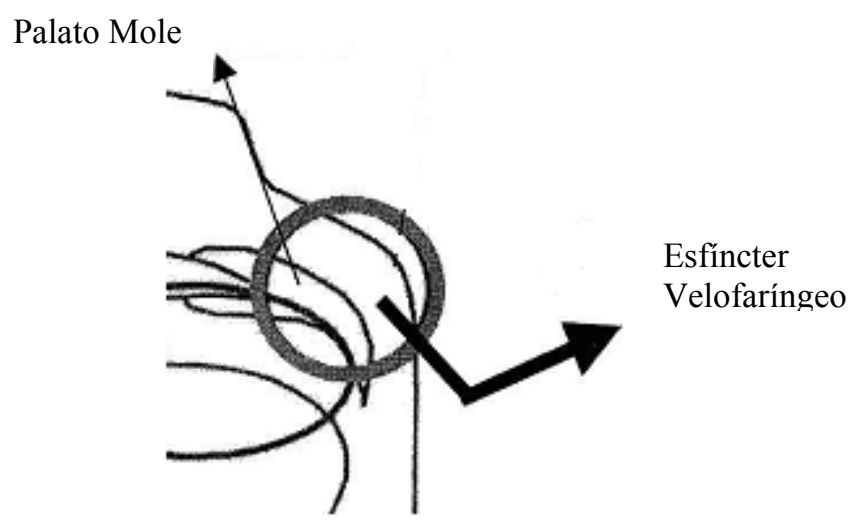

Figura 19 - Visão lateral do esfíncter velofaríngeo

Fonte: Adaptado de Shprintzen, 1997 
A função do esfíncter velofaríngeo é de separar a cavidade oral da cavidade nasal durante atividades pneumáticas como fala, sopro e assobio e não pneumáticas como deglutição e reflexo de vômito.

O fechamento adequado do esfíncter velofaríngeo, no processo de articulação dos fonemas orais, permite que a corrente aérea sonorizada e as vibrações acústicas sejam direcionadas para a cavidade oral onde, pela ação dos elementos articulatórios, produzirá a fala normal para a produção dos sons orais. Da mesma maneira, o fluxo de ar e as vibrações acústicas serão conduzidos para a cavidade nasal para a produção dos sons nasais (TRINDADE, 1996).

Anatomicamente, os músculos que compõem o esfíncter velofaríngeo são: elevador do véu palatino, constritor superior da faringe, palato-faríngeo, palato glosso e da úvula. Estes grupos musculares estão parcialmente interligados na altura do palato mole e todos estão presos a um arcabouço delimitado pelas estruturas da base do crânio, espinha cervical, lâmina lateral e medial do osso esfenóide e osso da maxila.

A disfunção velofaríngea pode provocar alterações na emissão da fala, e um dos sintomas mais comum é a hipernasalidade.

Quando existe uma falha neste mecanismo, a alteração na emissão da voz fica evidente, pois ocorre um acoplamento entre as cavidades oral e nasal, fazendo com que haja uma perda indesejada de fluxo de ar nasal durante a fala.

O não fechamento do esfíncter velofaríngeo, responsável pela alteração na ressonância da fala, está relacionado a diversas alterações. É decorrente de uma falta de tecido para efetuar o fechamento (insuficiência velofaríngea) ou de uma incapacidade do palato e/ou das estruturas faríngeas de se contraírem adequadamente para realizar o fechamento (incompetência velofaríngea). 
Estas disfunções do esfíncter velofaríngeo recebem o nome de causas orgânicas ou funcionais. As alterações tais como, fissura palatina, palato curto, perdas teciduais pósinfecção, ressecção de tumores e outros são causas orgânicas. Já as causas funcionais são: deficiência mental, deficiência auditiva, problemas emocionais, dentre outros. Podemos encontrar também as causas combinadas, que são a combinação das causas orgânicas e funcionais (TABITH, 1997). 


\section{Capítulo 4 - Avanços Tecnológicos}

O avanço da tecnologia eletrônica tem permitido analisar objetivamente as características acústicas vocais. Novos instrumentos tais como: DSP 5500 Digital Spectrograph e Nasômetro fabricados pela Kay Elemetrics são utilizados pelos especialistas para auxiliar, respectivamente, as análises vocais e as ressonâncias.

A análise do espectro acústico da voz é uma técnica que também pode fornecer informações valiosas a respeito da fala de indivíduos apresentando alguma patologia, inclusive disfunção velofaríngea. 


\section{1 - Avanços em Tecnologias Não-Invasivas}

Avaliações de pitch vocal e de ressonância são complementos úteis para exames tanto endoscópica quanto vídeoestroboscópica no diagnóstico de patologias vocais. A voz tem sido avaliada subjetivamente, ou seja, os julgamentos são feitos somente pela percepção do patologista vocal. Mesmo sendo freqüentemente usada, admite observações incorretas, particularmente em pacientes com patologia vocal (LABLANCE, 1991).

Avanços na tecnologia eletrônica têm resultado na capacidade de coletar dados objetivamente, analisando e exibindo características vocais rapidamente e com exatidão. Essa tecnologia inclui avaliações de pitch, perturbação de pitch (jitter), loudness (intensidade), ressonância do trato vocal e características da ressonância da cavidade oral $/$ nasal.

Vários instrumentos estão comercialmente disponíveis fornecendo avaliações detalhadas da voz. Instrumentos tais como, "PM 100 Pitch Analyzer" e "Visi-Pitch", são designados para estimar pitch. Já para características da ressonância das cavidades oralnasal do trato vocal, obtém-se melhores medidas quando analisadas pelo aparelho chamado Nasômetro (Key Elemetrics, Corp.). O aparelho a ser utilizado dependerá das características a serem estudadas.

Destes instrumentos citados acima, o "Visi-Pitch" e o Nasômetro são atualmente as técnicas mais sofisticadas e fornecem análises mais amplas da acústica da fala. Por essa razão são muito usados por pesquisadores e profissionais da área de saúde. Além disso, fornecem uma avaliação indireta da fisiologia do trato vocal através da interação dos componentes acústicos da voz com a vibração das pregas vocais. 
O "Visi-Pitch" foi desenvolvido em 1977 e consiste de microfone, processador de sinais e um microcomputador. O sinal vocálico é coletado pelo microfone e então enviado para o processador de sinais que irá extrair a freqüência fundamental (ou pitch) e a intensidade relativa da saída do sinal em tempo real. Os sinais são então enviados ao computador para análises gráficas e estatísticas. Os cursores são usados para agrupar o sinal no monitor e o computador calcula a freqüência fundamental média, intensidade relativa, perturbação de pitch, porcentagem de voz e silêncio além da porcentagem de pausa do sinal da fala. O gráfico exibe análise estatística que pode ser armazenada em disquete ou impressas.

O Nasômetro é uma técnica não invasiva, designado para avaliar a nasalância da voz (fluxo de ar oral-nasal durante a fala). A nasalância tem sido utilizada para medir o grau de nasalidade contida na voz. O aparelho capta separadamente os sons emitidos pelo nariz e pela boca através de dois microfones separados por uma barra horizontal colocada acima dos lábios. Ver figura 20.

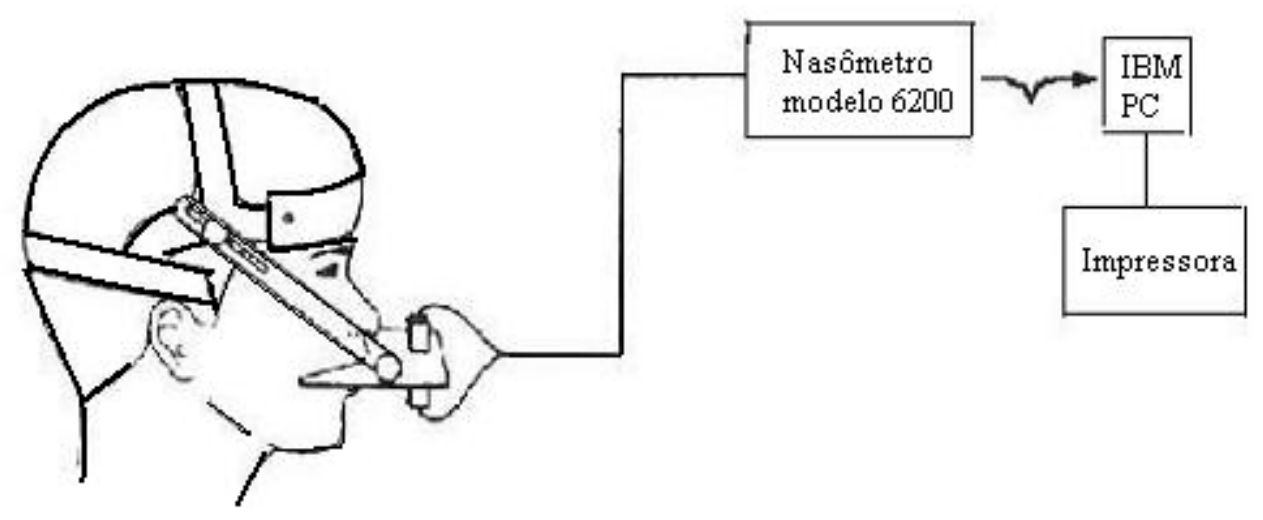

Figura 20 - Posicionamento do Nasômetro (Nasômetro 6200, Kay Eletremics Corp, Pine Brook, NJ, EUA)

Fonte: adaptado de Dalston et al., 1991 
Endoscopia e videoestroboscopia fornecem uma avaliação anatômica e fisiológica do trato vocal. A análise acústica avalia o desempenho dessas estruturas durante a produção da fala. Dados de cada um desses procedimentos são necessários para fornecer uma melhor avaliação da patologia vocal.

Patologias vocais podem afetar a freqüência fundamental, a intensidade e a qualidade. Por exemplo, insuficiência velar resulta em hipernasalidade, alterando a qualidade vocal.

Características ressonantes específicas do fluxo de ar oral/nasal durante a fala são medidas de nasalidade. Medida de nasalidade é crucial na avaliação de doenças que resultam em "defeito na ressonância", incluindo fissura palatal, incompetência velofaríngea, paralisia velar e problemas de audição. O sucesso da cirurgia maxilo-facial e a montagem protética são, em parte, dependente da avaliação exata do movimento velar e da ressonância nasal. Por causa de sua objetividade, a nasometria é o método de escolha quando se avalia nasalidade. 


\section{Capítulo 5 - Nasalidade}

A visão da estrutura velofaríngea durante a fonação tem sido considerada para avaliação de hipernasalidade. Vários meios instrumentais, tais como: vídeo fluroscopia e nasoendoscopia são responsáveis pela avaliação desses pacientes e estão disponíveis em clínicas médicas. Entretanto, algumas técnicas são invasivas causando desconforto ao paciente (KATAOKA, 1996).

Clinicamente, tem sido reconhecido que a fala de pacientes com disfunção velofaríngea (DVF) pode estar associada à hipernasalidade, à emissão de ar nasal e à presença de articulações compensatórias (ZAJAC, 1996).

A emissão de ar nasal é observada através de uma percepção que varia de inaudível a turbulento. As articulações compensatórias seria um recurso utilizado, pelos falantes com disfunção velofaríngea, para preservar a acústica normal da fala mesmo que para isto seja necessário sacrificar a posição da articulação. Um exemplo de movimento compensatório seria a assistênia lingual.

A função velofaríngea durante a produção de vogais de indivíduos normais também tem sido estudada por alguns pesquisadores utilizando técnicas de raio-X ou observações diretas. Estas investigações indicaram que nem sempre ocorre um fechamento completo da função velofaríngea durante a produção das vogais. Observou-se que nas vogais altas - /i/ e /u/ - ocorre um maior fechamento velofaríngeo quando comparadas com as vogais baixas - 
/æ/ e /a/. Estas vogais são classificadas como altas ou baixas devido ao posicionamento da língua e podem ser vistas na figura 21. Por exemplo, ao produzir a vogal /i/, a língua posiciona-se para o alto (de encontro ao palato), e arqueia-se para frente (de encontro aos lábios), sendo assim denominada de vogal alta anterior. Para a vogal /u/, a língua move-se para o alto e para trás. Desta forma, a vogal /u/ é chamada de alta posterior. De forma análoga as vogais /æ/ e /a/ são denominadas de vogais baixa anterior e baixa posterior, respectivamente (MOLL, 1962).
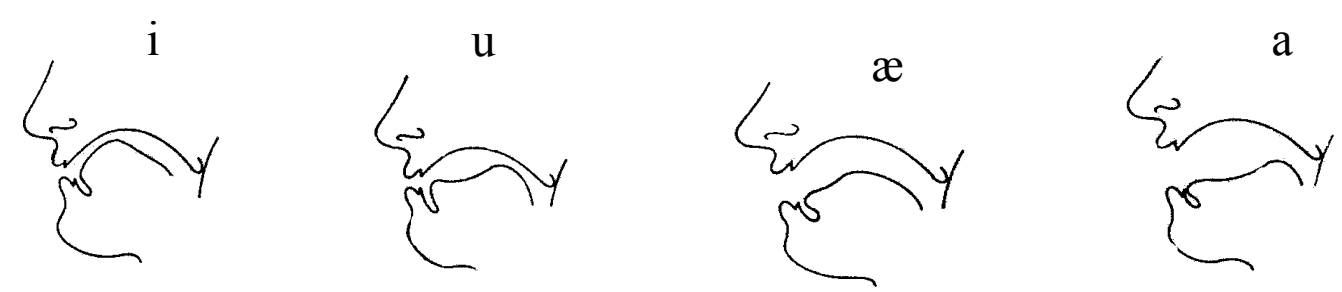

Figura 21 - Configuração do trato vocal durante a produção das vogais /a/, /i/, /u/ e /æ/

Fonte: Schwartz, M. F., 1968

As características das vogais dependem do contexto consonantal na qual está inserida e também de suas características fisiológicas, incluindo o fechamento velofaríngeo, variando também com o contexto fonético. Alguns pesquisadores acreditam que o contexto fonético pode afetar a característica do fechamento das vogais. Além disso, algumas vogais podem ser mais nasais dentro de um contexto consonantal do que em outros. Moll (1962) sugeriu que a função velofaríngea nas vogais sustentadas seria diferente das vogais observadas durante a fala encadeada.

Além destes trabalhos citados acima envolvendo nasalidade, alguns pesquisadores estudaram a possibilidade de selecionar crianças para adenoidectomia (remoção da 
adenóide) através da observação do grau de nasalidade, pois evidências sugeriram que a impressão subjetiva da fala nasal estava relacionada com o volume da adenóide.

Parker et al. (1989) sugeriram que os casos mais apropriados para remoção da adenóide seriam em crianças que respiravam pela boca, roncavam e sofriam de obstrução nasal. Mas encontraram problemas na seleção dos indivíduos para a cirurgia, pois a nasalidade é uma avaliação subjetiva, ou seja, é percebida por diferentes ouvintes e depende da experiência do profissional. Por esta razão, têm sido realizadas várias tentativas para avaliar a nasalidade objetivamente, e assim aumentar sua eficácia operatória. A principal técnica usada hoje inclui espectrograma, análise do fluxo/pressão velofaríngea e determinação da razão acústica oral e nasal através de uma escala de freqüência determinada. A razão acústica oral e nasal, foi primeiro proposto como sendo um método rápido e não-invasivo para determinar a nasalidade de um indivíduo objetivamente. Como esta técnica apresentava confiabilidade, tornou-se um instrumento comercialmente conhecido como Nasômetro. Os resultados deste estudo mostraram que o Nasômetro foi um instrumento de confiança e um indicador sensitivo para a obstrução nasal que pode ter um papel importante em ajudar o cirurgião a selecionar casos para adenoidectomia. Serão necessários estudos adicionais para determinar seu papel na seleção de crianças para adenoidectomia, de forma a permitir ao cirurgião uma avaliação objetiva de identificar préoperatoriamente as crianças para realizar a cirurgia, reduzindo o número de adenoidectomias realizadas desnecessariamente.

Algumas técnicas têm sido utilizadas para avaliar a qualidade vocal e a nasalização após adenoidectomia. Estas técnicas incluem: percepção auditiva; medidas aerodinâmicas (pressão/fluxo de ar) do trato nasal; avaliações radiográficas e acústicas. 
Andreassen et al. (1991) investigaram as mudanças na ressonância nasal após adenoidectomia em crianças. Foram analisadas a vogal alta anterior /i/ e a vogal baixa posterior /a/ através do aparelho Nasômetro. Acusticamente, as amostras apresentaram um aumento de nasalância após a cirurgia, seguida por continuada diminuição na nasalância. Resultados sugeriram que maiores mudanças na nasalância e razões perceptivas de nasalidade ocorreram no primeiro mês após a cirurgia e estas medidas foram se estabilizando após de três meses. Para os autores são necessários mais estudos para analisar acusticamente a nasalidade de uma maneira objetiva. Ao contrário de Parker et al. (1989), para Andreassen et al. (1994) as indicações mais comuns para adenoidectomia, com ou sem tonsilectomia, era somente obstrução nasal e infecção da via aérea nasal recorrente. Através de exames radiográficos, têm determinado que certos componentes da função velofaríngea são alterados após adenoidectomia, incluindo a perfeição do fechamento velofaríngeo e o comprimento velar durante sua função. Estudos adicionais mostraram claramente que existe uma maior dificuldade do mecanismo velofaríngeo pós-operatório em alcançar seu fechamento. Os grupos considerados de risco para disfunção velofaríngea pós-operatório eram crianças que apresentavam fissura palatal, incompetência palatal congênita, fissura palatal submucosa, paralisia facial, Síndrome de Down, história familiar de VPI ou fissura palatal, entre outros. Para o procedimento acústico os autores utilizaram o aparelho Nasômetro para coletar os dados e analisaram a razão acústica oral/nasal de quatorze crianças, sendo três garotos e onze garotas, submetidos a adenoidectomia com ou sem tonsilectomia. Foram estudadas as vogais baixa posterior /a/ e alta anterior /i/. Os resultados acústicos mostraram um aumento na classificação de nasalância logo após adenoidectomia, seguida por um leve aumento (ou estabilização) de nasalância com três meses, e depois de completados seis meses, houve uma redução. Esta redução pode ser 
explicada pelo estabelecimento gradual da posição da língua depois da adenoidectomia. Acusticamente, concluíram que a vogal /i/ apresentou maior nasalância. Segundo os exames radiográficos do fechamento velofaríngeo durante a produção de várias vogais, Moll (1992) registrou que o fechamento mais completo ocorre na produção de vogais altas /i/ e /u/ do que na vogal baixa /a/. Baseado nisto, a menor razão de energia acústica deveria ser esperada durante a produção de /i/ com uma razão comparavelmente maior para /a/. Mas o estudo de Andreassen et al (1994) não confirmou esta hipótese. Uma menor nasalância foi notada durante a vogal /a/. Isto pode estar relacionado com a maior ressonância oral enquanto pronunciava a vogal /a/, devido à posição da língua ser mais baixa e para trás. Estes dados são consistentes com os achados de outros pesquisadores quando relataram que avaliações de nasalidades severas são freqüentemente mais encontradas nas vogais altas do que nas baixas.

Desde a década de 40, têm sido realizadas análises espectrográficas dos sons da fala na tentativa de descrever as características espectrais associadas com nasalidade. Para isto, utilizam-se sons vocálicos produzidos de maneiras diferentes. Por exemplo, vogais nasais produzidas por falantes normais, ou seja, nasalidade; vogais produzidas por indivíduos funcionalmente nasais, isto é, tendo nasalidade sem patologia orgânica óbvia; e vogais produzidas por falantes apresentando nasalidade associada com fissura palatal ou deformidade oral similar (DICKSON, 1962).

House e Stevens (1956) estudando o espectro acústico de vogais nasais sintetizadas, concluíram que o efeito geral de incorporar o acoplamento nasal alarga e suaviza os picos no espectro vocálico. As mudanças espectrais mais evidentes ocorrem na região do primeiro formante, sendo razoável assumir, que estas mudanças podem ser de fundamental importância para nasalidade. Uma observação também interessante notada pelos 
pesquisadores é que as características específicas da nasalidade podem diferir para vogais diferentes bem como para indivíduos diferentes.

Dickson (1962) relatou que as características acústicas mais comuns relacionadas com nasalidade são:

1- Redução na intensidade do primeiro formante;

2- Redução da intensidade dos harmônicos de alta freqüência, incluindo a região do primeiro formante;

3- Uma anti-ressonância (regiões de intensidade muito reduzidas);

4- Aumento na largura de faixa dos formantes;

A ocorrência de várias características espectrais associadas com nasalidade parece ser dependente das propriedades físicas das cavidades nasais e do grau de acoplamento entre as cavidades oral e nasal. Ao analisar o espectro de alguns indivíduos classificados como nasais Dickson (1962) encontrou:

1- Um aumento na largura de banda do formante;

2- Um aumento ou diminuição na intensidade dos harmônicos;

3- Um aumento ou diminuição na freqüência formante;

4- Um aumento na freqüência fundamental;

5- Diminuição na energia das freqüências altas;

6- Intensidade reduzida do terceiro formante. 
Ele supôs que o aumento na freqüência fundamental pode estar relacionado, não com a nasalidade, mas sim com o esforço aumentado que alguns indivíduos classificados como nasais necessitaram para produzir a fala e citou a importância de enfatizar que características acústicas da nasalidade variam de indivíduo para indivíduo.

House e Stevens (1956), em estudo análogo, relataram que o aumento na largura de faixa dos formantes vocálicos ocorreu quando o acoplamento nasal foi introduzido.

Schwartz (1968) encontrou quatro características importantes observando o espectro de vogais nasais. A primeira destas, a mais freqüentemente notada, foi uma redução na intensidade do primeiro formante. Este efeito foi notado em todas vogais analisadas, a saber, /a/, /æ/, /i/ e /u/. Supôs que esta redução é devido à adição de características amortecedoras da cavidade nasal. A segunda característica encontrada no espectro vocálico nasal seria presença de antiressonância. Uma antiressonância, é um fenômeno acústico que ocorre quando um tubo (tal como a cavidade oro-faríngea) é acoplado a um tubo paralelo (cavidade nasal). A terceira característica seria a presença de harmônicos reforçados com freqüências onde a energia não é normalmente esperada. Estas freqüências reforçadas podem ser consideradas as ressonâncias da cavidade nasal. Finalizando, a quarta característica é a transferência das posições das freqüências relativas dos formantes. As mudanças deste gênero são esperadas desde que o acoplamento da cavidade nasal, efetivamente, mude as dimensões da cavidade oro-faríngea.

Kataoka (1996), estudando indivíduos com fala normal e indivíduos com fala hipernasal, encontrou picos e vales entre o primeiro e segundo formante nas vogais nasais, bem como irregularidade na faixa superior contendo o terceiro formante. 


\section{Capítulo 6 - Modelo Acústico}

A figura 22 mostra uma secção sagital média da anatomia do aparelho fonador. Os principais componentes deste sistema são os pulmões, a traquéia, a laringe (órgão que produz voz), cavidade faríngea (garganta), cavidade oral (boca) e cavidade nasal (nariz).

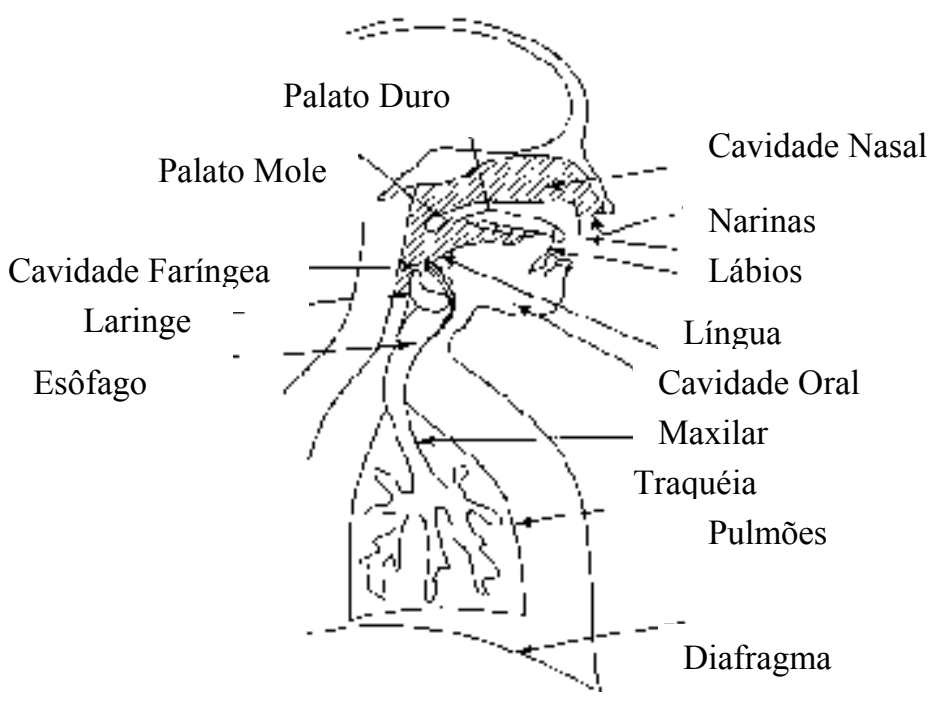

Figura 22 - Diagrama esquemático do mecanismo de produção da fala humana

Fonte: Adaptado de Deller, J.R.; Proakis, J.G.; Hansen, J.H.L, 1993.

Para discussão técnica, a cavidade oral e faríngea são usualmente agrupadas em uma única unidade denominada trato vocal e a cavidade nasal é freqüentemente chamada de trato nasal. $\mathrm{O}$ trato nasal inicia-se no velum e termina nas narinas. As características 
anatômicas importantes para a produção da fala incluem as pregas vocais, palato mole ou velum, língua, dentes e lábios. A ponta móvel do velum é chamada úvula. Esta move para diferentes posições para produzir vários sons que são conhecidos como articuladores. A mandíbula ou maxilar também é considerado um articulador, pois é responsável pelos movimentos que afetam o tamanho e a forma do trato vocal, bem como as posições de outros articuladores (DELLER et al., 1993).

Para os engenheiros é útil pensar na produção da fala em termos de um gerador glotal e de uma filtragem acústica. Assim a anatomia vocal será associada com um modelo matemático.

As cavidades do sistema de produção da fala (trato vocal e nasal) compreendem o principal filtro acústico. Os articuladores são associados ao filtro e são usados para mudar as características do sistema, suas formas de excitação e suas saídas com relação ao tempo. A figura 23 ilustra um modelo acústico simplificado.

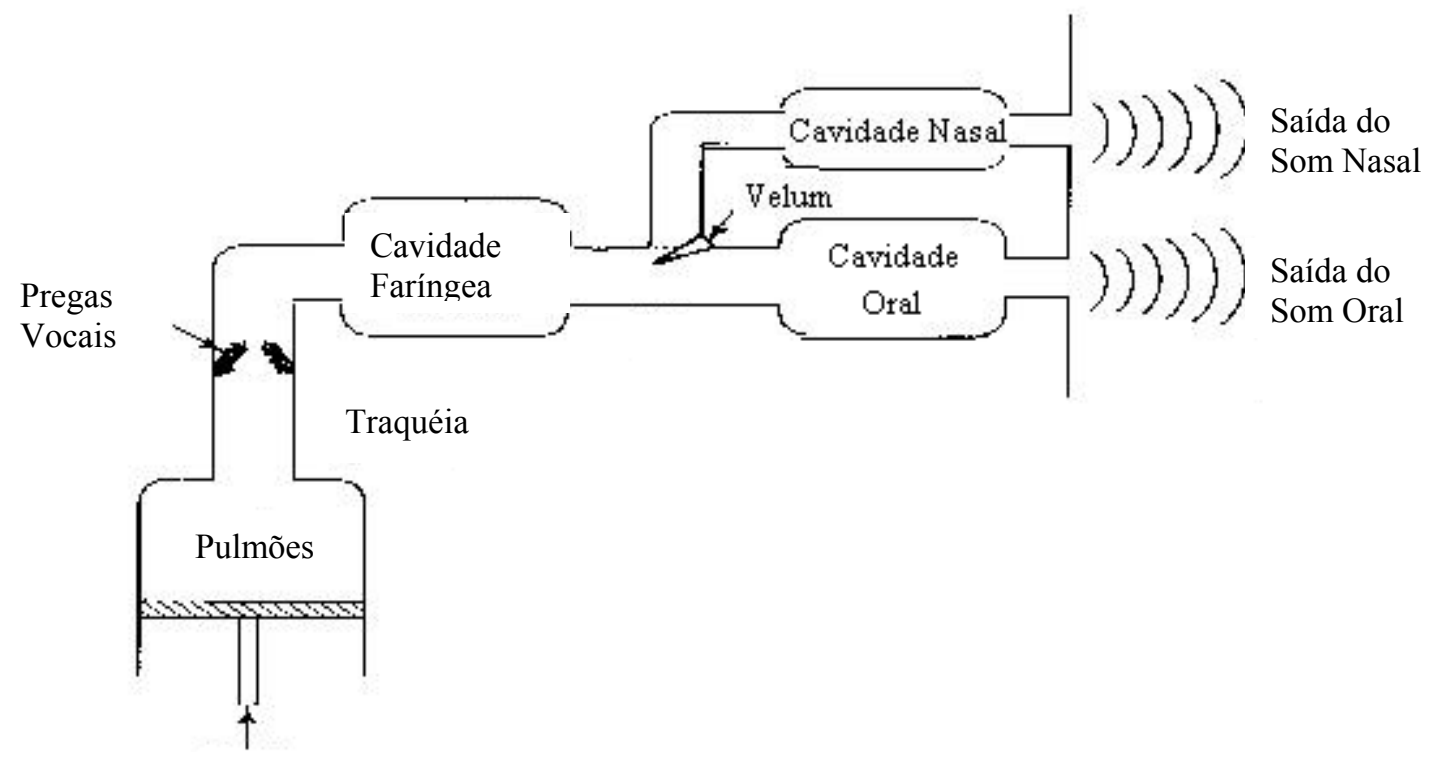

Figura 23 - Diagrama em bloco da produção da fala humana

Fonte: Adaptado de Deller, J.R.; Proakis, J.G.; Hansen, J.H.L, 1993 


\section{Capítulo 7 - Parâmetros Acústicos}

“Análise de Voz 2.3" é um programa de análise acústica que fornece vários parâmetros para analisar a voz. A saber, Jitter, Shimmer, Suavidade Espectral do Resíduo (SFR), Suavidade Espectral do Filtro (SFF), Pitch Amplitude (PA), Coeficiente de Excesso (Ex) e Freqüência Fundamental (Fo).

Jitter é definido como uma medida de perturbação da freqüência, correspondendo a variações de ciclo a ciclo.

Shimmer é definido como uma medida de perturbação da amplitude correspondendo a variações de ciclo a ciclo (PINHO et al., 2001).

Suavidade Espectral (SF), proposto por Markel (1976) avalia através do espectro do sinal a quantidade de ruído contida neste. Este parâmetro quantifica a distância do espectro do sinal em relação ao espectro do ruído branco (sinal ideal contendo todas as freqüências), considerado constante. Quando avaliado sobre o sinal residual da voz temos a Suavidade Espectral do Resíduo (SFR). Quando calculamos a Suavidade Espectral do Filtro (SFF) temos uma avaliação da forma do trato vocal, sendo um parâmetro apropriado para quantificar a nasalidade.

Pitch Amplitude (PA) é um parâmetro baseado na autocorrelação do sinal residual. A natureza da autocorrelação de um sinal é realçar estruturas periódicas (correlacionadas) ao mesmo tempo que amortece as componentes aleatórias. Portanto, a autocorrelação do sinal residual enfatiza a freqüência fundamental. Para sons bem vocalizados o PA 
aproxima-se da unidade, enquanto para sons não vocalizados (consoantes) o PA vale zero. Assim, o parâmetro PA estabelece uma escala de vocalização.

Coeficiente de Excesso (Ex) é um parâmetro que avalia a distribuição de amplitudes de um sinal. Intrinsecamente, este parâmetro quantifica um correlato da relação sinal-ruído. Inúmeros parâmetros têm sido propostos na literatura. Basicamente, três características do sinal de voz são analisadas, a saber: período (ou seu inverso - a freqüência), amplitude (ou intensidade) e a forma do sinal. Portanto, os inúmeros parâmetros apresentam enorme redundância.

Também várias técnicas de processamento são utilizadas visando estabelecer parâmetros mais robustos e/ou mais adequados à determinada análise. Dentre estas técnicas podemos citar a análise espectral, a análise cepstral, a técnica inversa residual além da técnica direta (sinal de voz).

$\mathrm{Na}$ figura 24 apresentamos uma sistematização dos diversos parâmetros propostos na literatura.

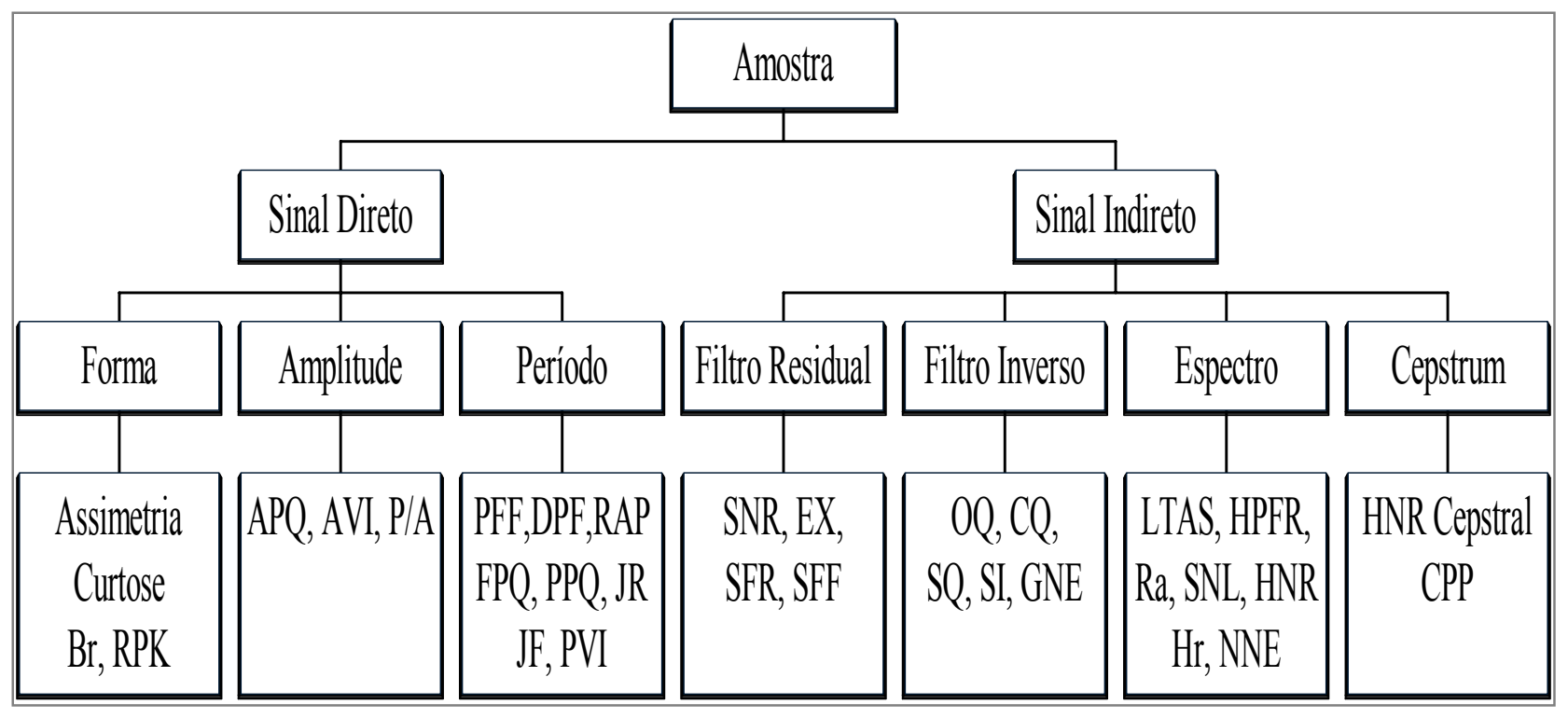

Figura 24 - Diagrama esquemático dos diversos parâmetros propostos na literatura 
Medidas da perturbação em freqüência avaliam as variações da freqüência ou equivalentemente do período do sinal. Existem vários parâmetros acústicos, citados abaixo, sugeridos na literatura que são utilizados para quantificar o Jitter. Variações abruptas na freqüência fundamental durante a fonação indicam aspereza no som e estes parâmetros são úteis para este diagnóstico. São exemplos de Jitter:

Fator de Perturbação em Frequência (PFF) - Proposto por Lierbeman (1963, 1967). Este parâmetro representa a freqüência relativa das perturbações do período de pitch maiores que $0,5 \mathrm{~ms}$.

Fator de Perturbação Direcional (DPF) - Sugerido por Hecker e Kruel (1961). Utilizado para contabilizar o número de vezes que a diferença entre períodos sucessivos muda de sinal algébrico.

Perturbação Média Relativa (RAP) - Koike (1973) propôs este parâmetro, que é análogo ao PFF, para medir a flutuação dos períodos de pitch. A diferença entre períodos é calculada usando-se o período atual e uma média entre o anterior, o atual e o posterior. Koike utiliza uma janela de 3 períodos.

Quociente de Perturbação de Frequência (FPQ) - Takahashi e Koike (1977) utilizaram a mesma fórmula do RAP substituindo o período pela freqüência.

Quociente de Perturbação de Período de Pitch (PPQ) - Davis (1979) utilizou a mesma fórmula do RAP, mas calculado para uma janela de 5 períodos. Davis determinou que esta janela fornece maior confiabilidade.

Razão de Jitter (JR) - Sugerido por Horii (1979), fornece a relação entre a média das perturbações pelo período médio. 
Fator de Jitter (JF) - Proposto por Murry e Doherty (1980). É semelhante ao JR, porém é definido para valores de freqüência.

Índice de Variabilidade Período (PVI) -Definido por Deal e Emanuel (1978). Basicamente, deriva do coeficiente de variação $(\mathrm{CV})$ aplicado ao período do sinal em toda a amostra.

A medida da variação também pode ser útil ao se calcular sobre a amplitude do sinal. Na literatura as medidas de perturbação em amplitude citadas mais freqüentemente são:

Quociente de Perturbação de Amplitude (APQ) - Definido por Takahashi e Koike (1975). Ao se usar a amplitude do sinal na fórmula do RAP com 5 janelas temos o parâmetro APQ.

Índice de Variabilidade Amplitude (AVI) - Proposto por Deal e Emanuel (1978). Este parâmetro avalia a perturbação da amplitude normalizada pelo quadrado da média.

Assimetria e Curtose são parâmetros considerados de ordem superior. O primeiro é a regularidade da distribuição normal dos parâmetros e a curtose a suavidade da distribuição.

Existem inúmeros parâmetros citados na literatura que analisam a proporção de sinal/ruído contida num sinal. A saber:

Nível Espectral de Ruído (SNL) - Sugerido por Sansone e Emanuel (1970). É um parâmetro utilizado para diferenciar vozes normais das ásperas. O procedimento de cálculo era realizado sobre curvas de densidade de potência espectral impressas em papel milimetrado. 
Espectro Médio de Tempo Longo (LTAS) - Frokjaer-Jensen (1976). Este parâmetro é determinado pela média do espectro obtida de um segmento de voz de $80 \mathrm{~ms}$ de uma amostra de voz de $45 \mathrm{~s}$.

Harmônicas Relativas (Ra) - Kojima (1980) definiu este parâmetro para relacionar a energia entre componentes harmônicas e ruidosas de um sinal construído a partir de trechos com período de freqüência fundamental. Este parâmetro é capaz de diferenciar vozes soprosas de ásperas.

Relação Harmônicas/Ruído (HNR) - Definido por Yumoto (1982), quantifica elementos do sinal de voz patológico, tais como: componentes aleatórios na região da freqüência formante, aparecimento de ruído de alta freqüência e perda de magnitude nas freqüências harmônicas.

Intensidade Relativa de Harmônicas (Hr) - Sugerido por Hiraoka (1984), avalia a rouquidão na fala sustentada. Baseia-se na densidade de potência espectral para avaliar a relação entre as componentes harmônicas e as não harmônicas.

Energia de Ruído Normalizada (NNE) - Kasuya (1986) desenvolveu um parâmetro no domínio da freqüência para estimar o ruído entre as componentes harmônicas, suportando alterações suaves na amplitude e período.

Relação de Soprosidade (Br) - Desenvolvido por Fukazawa (1988), permite uma avaliação simples do ruído de turbulência produzido pela glote na condição disfônica (soprosidade). A medida $\mathrm{Br}$ corresponde ao percentual de energia de alta freqüência por energia total do sinal.

Relação de Potência em Altas Freqüências (HFPR) - Shoji (1992). Utiliza-se para avaliar o ruído de alta freqüência. Determina-se a partir do sinal de voz normalizando a 
média das curvas de densidade de potência espectral, em escala logarítmica, com deslocamento de 25,6 ms entre cada estimativa.

Relação Harmônicas/Ruído (CNR) Cepstral - Hillenbrand (1994) desenvolveu este parâmetro idêntico ao HNR, porém avaliado no domínio cepstral.

Relação Pico/Amplitude (P/A) - Definido por Hillenbrand (1994), corresponde à razão entre a máxima amplitude no segmento de voz analisado pela amplitude média da retificação em onda completa deste mesmo trecho.

Proeminência de Pico Cepstral (CPP) - Hillenbrand (1994) definiu CPP como a diferença entre a amplitude do pico cepstral e o valor correspondente na regressão linear em um intervalo analisado. É útil na avaliação de vozes soprosas.

Pearson r na Autocorrelação do Pico (RPK) - Hillenbrand (1994). É obtido pelo cálculo de coeficiente de Pearson entre o sinal de voz e a sua versão deslocada k amostras, onde $\mathrm{k}$ corresponde ao ponto de ocorrência do segundo máximo da função de autocorrelação do trecho analisado.

Também foram propostos parâmetros para avaliar as medidas em relação ao sinal residual. A saber:

Relação Sinal Ruído (SNR) - Equivalente ao SNL, porém avaliado no domínio do tempo.

Coeficiente de Excesso (EX) - Davis (1979)

Amplitude de Pico da Autocorrelação (PA) - (1979)

Suavidade Espectral (SF) - Davis (1979)

Suavidade Espectral do Resíduo (SFR)

Suavidade Espectral do Filtro (SFF) 
Estes cinco parâmetros citados anteriormente foram explicados no início deste capítulo.

Para finalizar, temos parâmetros que analisam medidas em relação ao pulso glotal de um sinal. A saber:

Quociente de Abertura ou Quociente de Abdução (OQ);

Quociente de Fechamento (CQ);

Quociente de Velocidade (SQ);

Índice de Velocidade (SI);

Razão de Excitação glotal (GNE) - Michaelis (1997). 


\section{Capítulo 8 - Programa "Análise de Voz 2.3"}

O uso de instrumentos computacionais objetiva quantificar e fornecer medidas mais acuradas das características do sinal de voz. "Análise de Voz 2.3" é um programa que analisa as condições da laringe quantitativamente.

Ao abrir o programa aparece a primeira tela, como mostra a figura 25, proporcionando oito botões de opções.

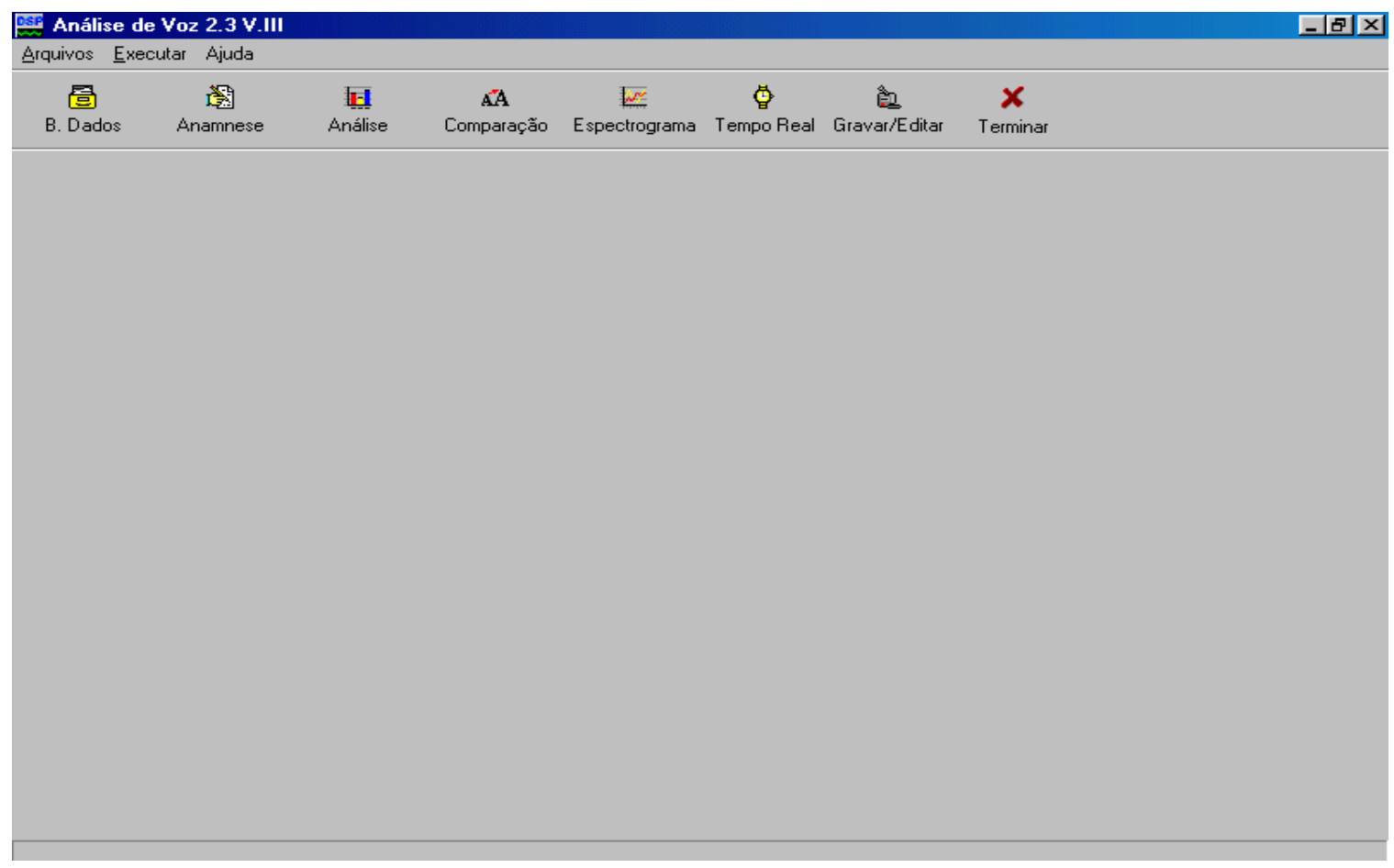

Figura 25 - Tela inicial exibida pelo programa “Análise de Voz 2.3” 
Na primeira opção temos o banco de dados, /B. Dados/. Aqui estão guardadas todas as vozes anteriormente gravadas. $\mathrm{Na}$ opção /Anamnese/ pode-se arquivar todas as anotações gerais dos pacientes. A opção /Análise/, analisa o espectro do sinal de voz (será discutido em detalhes logo adiante). Em /Comparação/ pode-se comparar dois sinais de voz simultaneamente (também será discutido em detalhes adiante). Na opção /Espectrograma/, o sinal vocal é analisado através de tonalidades de cores ou em preto e branco. Ao explorar a opção /Tempo Real/, como o próprio nome sugere, possibilita analisar em tempo real. Para gravar e guardar as amostras vocais utiliza-se o botão /Gravar-Editar/. Para finalizar o programa basta selecionar a opção /Terminar/.

Dentre todas estas opções disponíveis no programa, apenas três foram utilizadas neste trabalho de mestrado, a saber: /Gravar-Editar/, /Comparação/ e /Análise/.

O recurso /Comparação/ exibe na tela do computador a figura 26. Do lado esquerdo desta figura, temos dois trechos vocais para efeito de comparação entre dois sinais, sendo no campo superior um sinal representado na cor azul e no campo inferior outro sinal na cor amarelo. Selecionando no menu /abrir/ do primeiro campo (sinal representado na cor azul), pode-se escolher o arquivo de voz a ser analisado. O mesmo procedimento pode ser seguido para abrir o arquivo no segundo campo. Geralmente, este recurso é utilizado para o acompanhamento da evolução de um mesmo paciente. Neste trabalho, foi utilizado com a finalidade de comparar as características das vogais /a/ oral e /a/ nasal.

A amostra visualizada na cor azul representa o trecho vocal da vogal /a/ oral e a que está na cor amarela é a vogal /a/ nasal, ambas analisadas no domínio do tempo. Para realizar a análise de qualquer um dos campos deve-se selecionar com o mouse sobre o sinal obtendo o trecho a ser analisado, representado pelo traço em vermelho também visualizado na figura 26. Por motivos de instabilidades fonatórias foram excluídos os trechos iniciais e 
finais da gravação. Após o procedimento de seleção, o programa automaticamente faz a análise e a média do número de amostras escolhidas, apresentando os resultados na forma numérica e em barras.

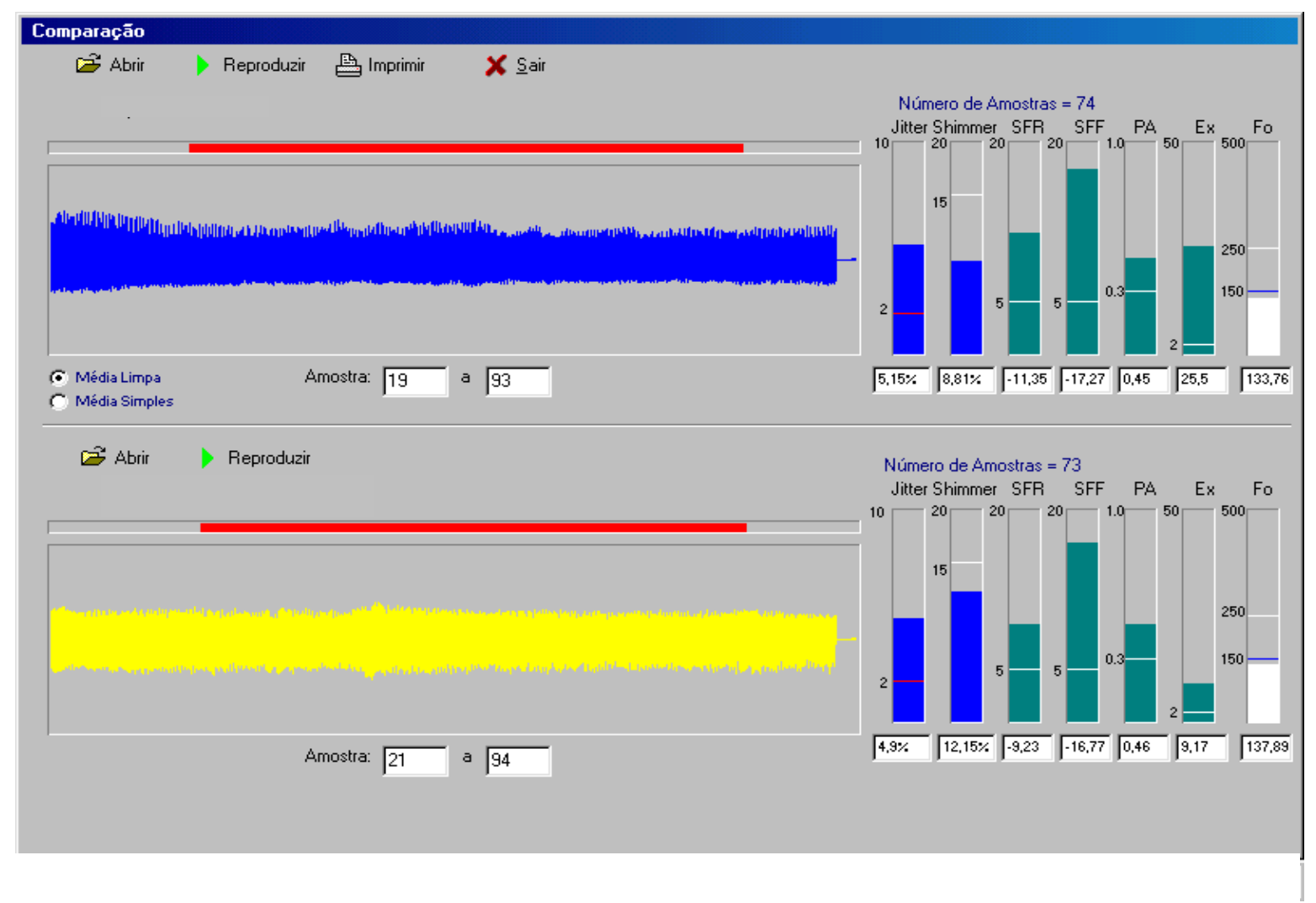

Figura 26 - Visualização da tela exibida pelo recurso "Comparação"

Do lado direito da figura 26, tanto na parte superior como na inferior, vemos os sete parâmetros dispostos no formato de colunas (todos os parâmetros foram explicados no capítulo 7). Os dois primeiros parâmetros são amostrados em porcentagem. Do terceiro ao sexto utiliza-se uma escala em $\mathrm{dB}$ e o último está amostrado em ciclos/segundos. $\mathrm{O}$ valor limite para todos os parâmetros foi estabelecido sobre uma população sem anomalias na laringe através de técnicas estatísticas. 
Os parâmetros Jitter e Shimmer são mostrados na cor azul para indicar sua natureza progressiva, ou seja, para valores menores que o limiar (representado pelo traço branco nas escalas) a porção do sinal sendo analisada apresenta-se normal quanto a estes parâmetros. No entanto, se os valores calculados ultrapassam estes valores, o traço torna-se vermelho para indicar que o parâmetro está fora do padrão. Os parâmetros SFR, SFF, PA e Ex são de cores verdes para indicar sua natureza inversa, isto é, quanto maior forem seus valores, mais próximos da condição de voz normal. Desta forma, para valores abaixo do traço limiar, este torna-se de cor vermelha. Para finalizar, a freqüência fundamental está representada na coluna de cor branca. Ela possui dois níveis de limiar, sendo o primeiro de $160 \mathrm{~Hz}$ para vozes masculinas e o segundo de $250 \mathrm{~Hz}$ para vozes femininas. Uma vez ultrapassado qualquer um destes valores, os traços também mudam de cor. Os valores numéricos de todos os parâmetros podem ser vistos nas bases de cada coluna.

Ao utilizar o recurso "Análise”, tem-se a figura 27.

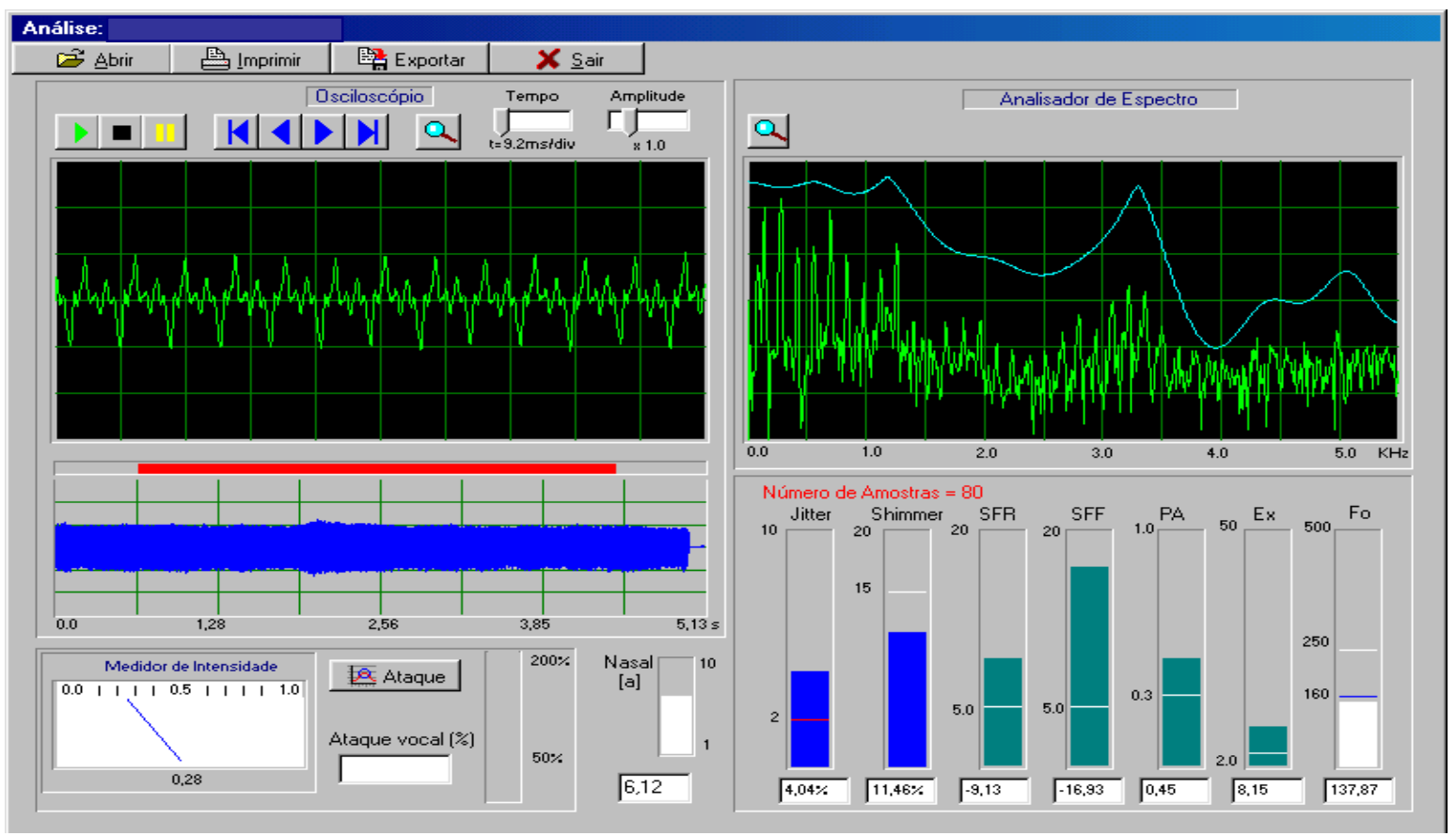

Figura 27 - Visualização da tela exibida pelo recurso "Análise" 
Este recurso analisa o espectro vocálico (sinal analisado no domínio da freqüência). A primeira tela do lado esquerdo na parte superior da figura 27 vemos o osciloscópio. Este mostra a porção do sinal a ser processada (representada no domínio do tempo).

Podemos selecionar o trecho a ser analisado pressionando o mouse sobre o sinal de cor azul. O traço em vermelho nos mostra o trecho a ser analisado. Após ter selecionado, podemos observar do lado direito da mesma figura o número de amostras vocais, os sete parâmetros mencionados anteriormente e o Analisador de Espectro.

Para uma melhor visualização do “Analisador”, pode-se selecionar a lupa, obtendo a figura 28.

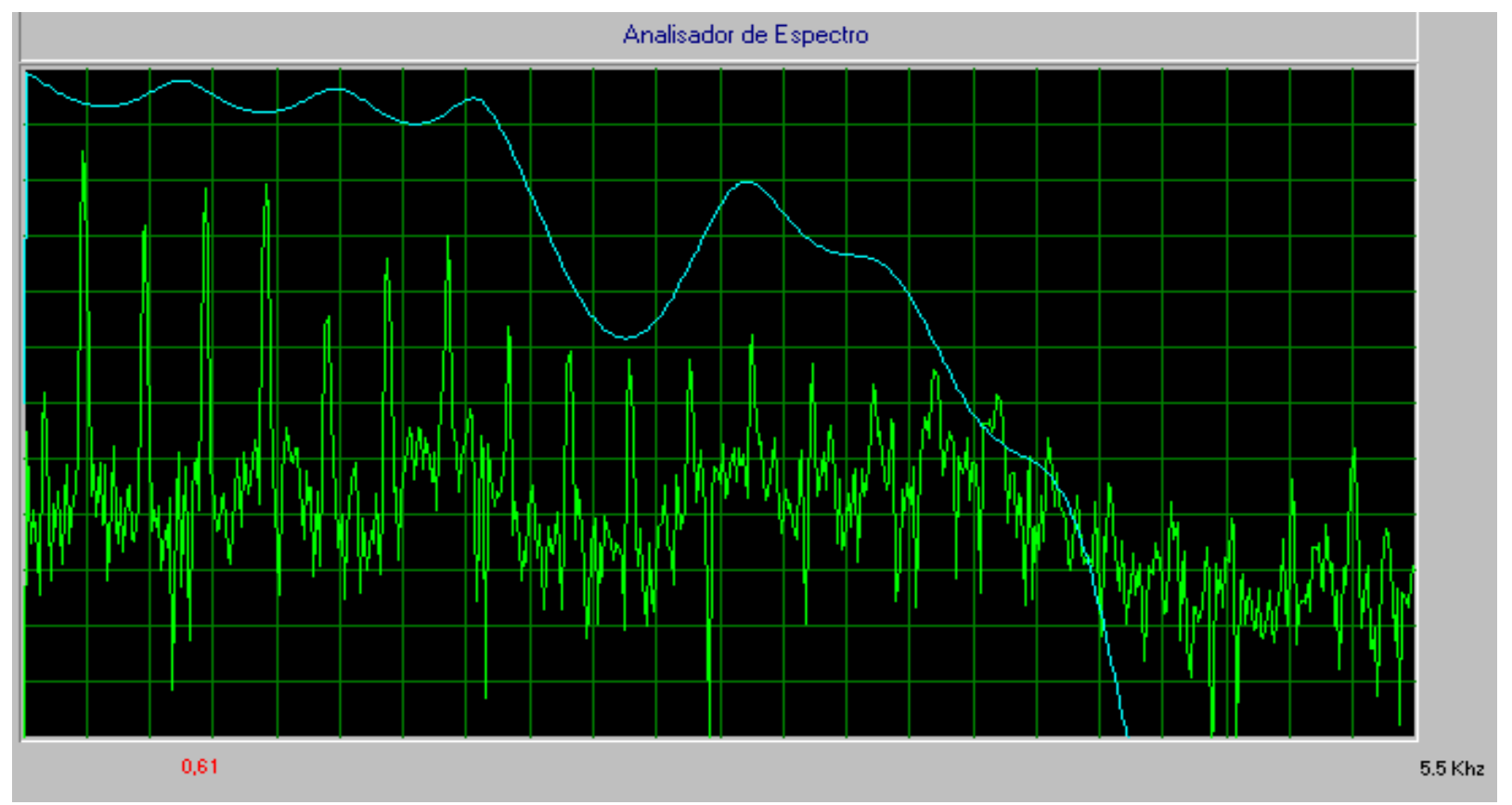

Figura 28 - Visualização da tela exibida pelo do recurso "Analisador de Espectro"

Os eixos horizontal e vertical representam, respectivamente, a freqüência em khz e a amplitude em dB. A curva mostrada em azul, representa as cavidades do trato vocal e nasal, quando este for acoplado. A curva em verde representa a freqüência fundamental e seus 
respectivos harmônicos. Percorrendo com o mouse sobre esta figura aparecem os valores dos primeiro, segundo e terceiro formantes. Para exemplificar, na figura 28 observa-se que o valor do primeiro formante para esta amostra vocal é de $610 \mathrm{~Hz}$.

Para finalizar, na parte inferior à esquerda da figura 27 temos o medidor de intensidade vocal. 


\section{Capítulo 9 - Material e Método}

Foram analisadas amostras vocais de 25 voluntários, sendo 11 vozes de mulheres e 14 vozes de homens, com idades variando entre 25 e 33 anos. Estas amostras foram compostas por alunos de pós-graduação do Departamento de Bioengenharia e por alunos de graduação e pós-graduação do Departamento de Engenharia Elétrica da Universidade de São Paulo - campus São Carlos.

Os critérios de seleção para os voluntários destas amostras foram: fumantes e não fumantes; todos são brasileiros; não apresentavam problemas auditivos e nem problemas neurológicos e não estavam gripados no dia da gravação.

Para todos os voluntários compostos nesta amostra foi esclarecido qual a finalidade deste estudo.

Nosso objetivo foi analisar, quantitativamente, a nasalidade através do espectro vocálico, visando determinar um parâmetro capaz de mensurar a nasalância.

As vozes foram captadas pelo microfone da marca LeSon, modelo SM 58 e para analisá-las foi utilizado o programa "Análise de Voz 2.3" desenvolvido no Departamento de Engenharia Elétrica desta Universidade.

Os voluntários produziram a vogal /a/ de duas maneiras: primeiramente foi pedido para sustentar a vogal /a/ oral pronunciada de maneira confortável por aproximadamente 5 segundos e depois sustentar a vogal /a/ nasal também por aproximadamente 5 segundos. 
Foram realizadas várias gravações para cada voluntário e depois foi escolhida a que apresentou uma melhor sonorização, ou seja, amostra mais adequada. Foi necessário um número maior de amostras para a vogal /a/ nasal devido à dificuldade para pronunciá-la.

Todos os voluntários permaneceram na posição sentada durante as gravações das respectivas vogais. Seus pés permaneceram apoiados ao chão e seus braços localizados sobre as pernas. A distância do microfone à boca foi mantida em $10 \mathrm{~cm}$. Para analisar as amostras vocais, os trechos iniciais e finais de todas as gravações foram desconsiderados, pois nestes trechos ocorrem instabilidades fonatórias.

As vozes foram gravadas no Laboratório de Instrumentação e Microeletrônica do Departamento de Engenharia Elétrica da USP. Esta sala não possui isolamento acústico, mas tomou-se cuidados em realizar as gravações somente nos períodos noturnos, aos finais de semana e também nos feriados. Desta forma pudemos diminuir a possibilidade de captação de ruídos indesejáveis tais como: conversas, barulhos de portas, etc. Todos os outros microcomputadores contidos nesta sala, bem como o ar condicionado, permaneceram desligados durante as gravações.

Para analisar as vogais orais e nasais, foram utilizados dois recursos fornecidos pelo programa “Análise de Voz 2.3", a saber, recurso "Comparação" e recurso "Analisador”. 


\section{Capítulo 10 - Resultados}

As vogais /a/ oral e /a/ nasal foram analisadas primeiramente utilizando o recurso “Comparação" do programa "Análise de Voz 2.3” e posteriormente analisadas pelo recurso "Analisador".

\section{1 - Recurso "Comparação"}

Os parâmetros Jitter, Shimmer, SFR, SFF, PA, Ex e Fo foram analisados para todas as amostras vocais.

Dos parâmetros avaliados, a porcentagem de Jitter teve maior variação ao passo que para Shimmer; SFR; SFF; PA; Ex e Fo estas variações foram desprezíveis, como podem ser observadas nas figuras de 30 a 33. Desta forma foi analisado somente o parâmetro Jitter.

As amostras foram separadas em dois grupos: grupo feminino e grupo masculino. Os dados foram dispostos em forma de tabela conforme esses dois grupos.

Para o grupo feminino, de onze casos analisados, em seis foi observado que o Jitter da voz oral era superior ao da voz nasal. No grupo masculino este fato foi observado em seis casos dos quatorze analisados. Apenas um caso mostrou mesmo percentual de Jitter para voz oral e voz nasal. Ver tabela 1. 
Tabela 1 - Análise do parâmetro Jitter para vozes do grupo feminino e masculino

\begin{tabular}{ccl}
\hline $\begin{array}{c}\text { Parâmetro } \\
\text { Acústico }\end{array}$ & $\begin{array}{l}\text { Número de casos onde o } \\
\text { Jitter da voz oral foi } \\
\text { maior }\end{array}$ & $\begin{array}{l}\text { Número de casos onde o } \\
\text { Jitter da voz nasal foi } \\
\text { maior }\end{array}$ \\
\hline $\begin{array}{c}\text { Jitter } \\
\text { (vozes femininas) }\end{array}$ & 6 & 5 \\
\hline Jitter & 6 & 7 \\
(vozes masculinas) & & \\
\hline
\end{tabular}

O próximo passo foi calcular quanto variou, percentualmente, o valor de Jitter para as vogais orais e nasais. Os valores foram obtidos através de cálculos matemáticos simples.

Para ilustrar estes cálculos, a figura 29 mostra a porcentagem de Jitter de um voluntário aleatório. O valor exibido de Jitter foi 4,97\% para a vogal oral e para a vogal nasal foi $0,45 \%$. Através da fórmula abaixo, concluiu-se que o Jitter nasal desta amostra diminuiu em 90,95\% do Jitter oral.

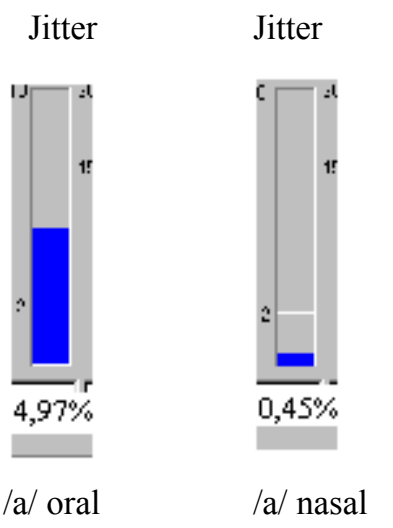

Figura 29 - Porcentagens de Jitter. À esquerda vogal /a/ oral e a direita /a/ nasal 
Dada a fórmula

$$
\mathrm{V}_{\mathrm{j}}=\frac{\mathrm{J}_{\mathrm{na}-} \mathrm{J}_{\text {oral }}}{\mathrm{J}_{\text {oral }}} \times 100
$$

sendo: $\mathrm{V}_{\mathrm{j}}$ - variação de Jitter;

$\mathrm{J}_{\mathrm{na}}-\mathrm{Jitter}$ da vogal /a/ nasal;

$\mathrm{J}_{\text {oral }}-\mathrm{Jitter}$ da vogal /a/ oral

calculou-se as variações percentuais de Jitter para todas as amostras. Os valores estão exibidos nas tabelas 2 e 3 . Os valores negativos contido na segunda coluna das tabelas 2 e 3, indicam o quanto diminuiu, em porcentagem, o parâmetro Jitter.

Tabela 2 - Variação percentual de Jitter para as vozes do grupo feminino

\begin{tabular}{cccc}
\hline $\begin{array}{c}\text { Porcentagem de } \\
\text { Jitter } \\
\text { (voz oral>voz nasal) }\end{array}$ & $\begin{array}{c}\text { Variação } \\
\text { Percentual }\end{array}$ & $\begin{array}{c}\text { Porcentagem de } \\
\text { Jitter } \\
\text { (voz nasal>voz oral) }\end{array}$ & $\begin{array}{c}\text { Variação } \\
\text { Percentual }\end{array}$ \\
\hline $1,41 \%-0,31 \%$ & $-78,01$ & $1,98 \%-0,39 \%$ & $-80,30$ \\
\hline $4,56 \%-2,46 \%$ & $-46,05$ & $2,36 \%-0,99 \%$ & $-58,05$ \\
\hline $4,97 \%-0,45 \%$ & $-90,95$ & $5,94 \%-3,89 \%$ & $-34,51$ \\
\hline $7,76 \%-3,04 \%$ & $-60,82$ & $2,34 \%-0,34 \%$ & $-85,47$ \\
\hline $4,62 \%-4,33 \%$ & $-6,28$ & $7,75 \%-1,32 \%$ & $-82,97$ \\
\hline $3,52 \%-0,42 \%$ & $-88,07$ & & \\
\hline
\end{tabular}


Tabela 3 - Variação percentual de Jitter para as vozes do grupo masculino

\begin{tabular}{lccc}
\hline $\begin{array}{c}\text { Porcentagem de } \\
\text { Jitter } \\
\text { (voz oral>voz nasal) }\end{array}$ & $\begin{array}{c}\text { Variação } \\
\text { Percentual }\end{array}$ & $\begin{array}{c}\text { Porcentagem de } \\
\text { Jitter } \\
\text { (voz nasal>voz oral) }\end{array}$ & $\begin{array}{c}\text { Variação } \\
\text { Percentual }\end{array}$ \\
\hline $0,29 \%-0,27 \%$ & $-6,90$ & $3,94 \%-0,29 \%$ & $-92,64$ \\
\hline $2,85 \%-1,68 \%$ & $-41,05$ & $1,27 \%-0,43 \%$ & $-66,14$ \\
\hline $8,07 \%-0,27 \%$ & $-96,65$ & $7,65 \%-0,21 \%$ & $-97,25$ \\
\hline $0,32 \%-0,24 \%$ & $-25,00$ & $4,24 \%-1,52 \%$ & $-64,15$ \\
\hline $5,15 \%-4,90 \%$ & $-4,85$ & $6,73 \%-2,01 \%$ & $-70,13$ \\
\hline $1,73 \%-0,76 \%$ & $-56,07$ & $6,65 \%-5,58 \%$ & $-16,09$ \\
\hline
\end{tabular}

$\mathrm{Na}$ tabela 4, encontram-se os valores médios da variação percentual de Jitter para os dois grupos. A variação percentual média para a vogal oral do grupo feminino foi maior quando comparada com o grupo masculino, $61,70 \%$ e $38,42 \%$ respectivamente. Entretanto, para as vogais nasais houve pouca variação, 68,26\% para o grupo feminino e $66,57 \%$ para o masculino.

Comparando a variação média de Jitter da vogal oral com a da vogal nasal do grupo feminino, foram $61,70 \%$ e 68,26\% respectivamente. Já para o grupo masculino esta variação foi maior, $38,42 \%$ e $66,57 \%$ respectivamente. 
Tabela 4 - Variação percentual média do parâmetro Jitter para os grupos feminino e masculino

\begin{tabular}{|c|c|c|c|}
\hline $\begin{array}{l}\text { Variação Média } \\
\text { de Jitter para o } \\
\text { grupo feminino } \\
\text { (voz oral > voz nasal) }\end{array}$ & $\begin{array}{l}\text { Variação Média } \\
\text { de Jitter para o } \\
\text { grupo masculino } \\
\text { (voz oral > voz nasal) }\end{array}$ & $\begin{array}{l}\text { Variação Média } \\
\text { de Jitter para o } \\
\text { grupo feminino } \\
\text { (voz nasal > voz oral) }\end{array}$ & $\begin{array}{l}\text { Variação Média } \\
\text { de Jitter para o } \\
\text { grupo masculino } \\
\text { (voz nasal > voz oral) }\end{array}$ \\
\hline $61,70 \%$ & $38,42 \%$ & $68,26 \%$ & $66,57 \%$ \\
\hline
\end{tabular}

Algumas amostras das análises feitas através do recurso "Comparação" podem ser vistas nas figuras de 30 a 33 . 


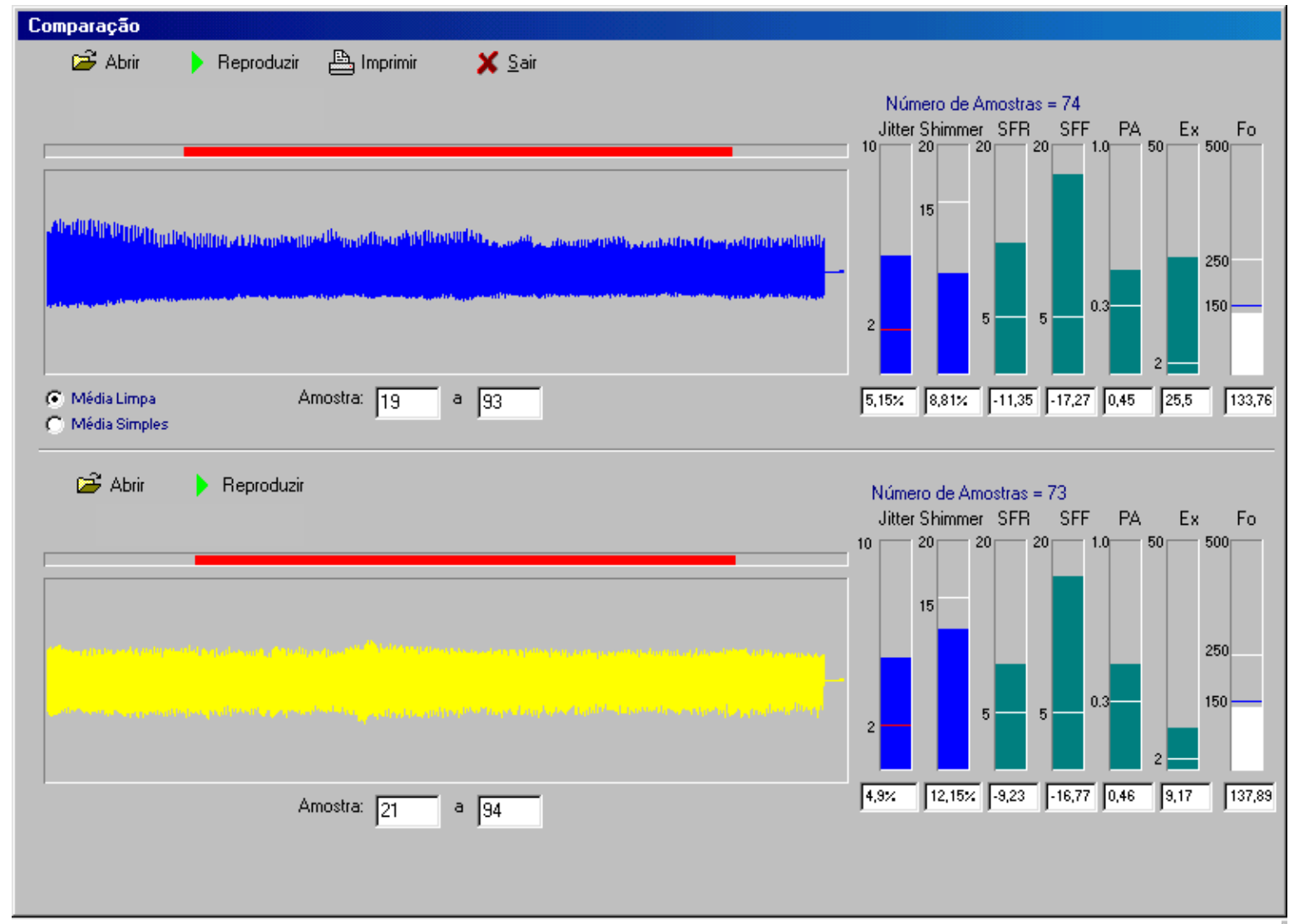

Figura 30 - Amostra do grupo masculino onde a porcentagem do parâmetro Jitter da vogal oral foi maior que o da vogal nasal

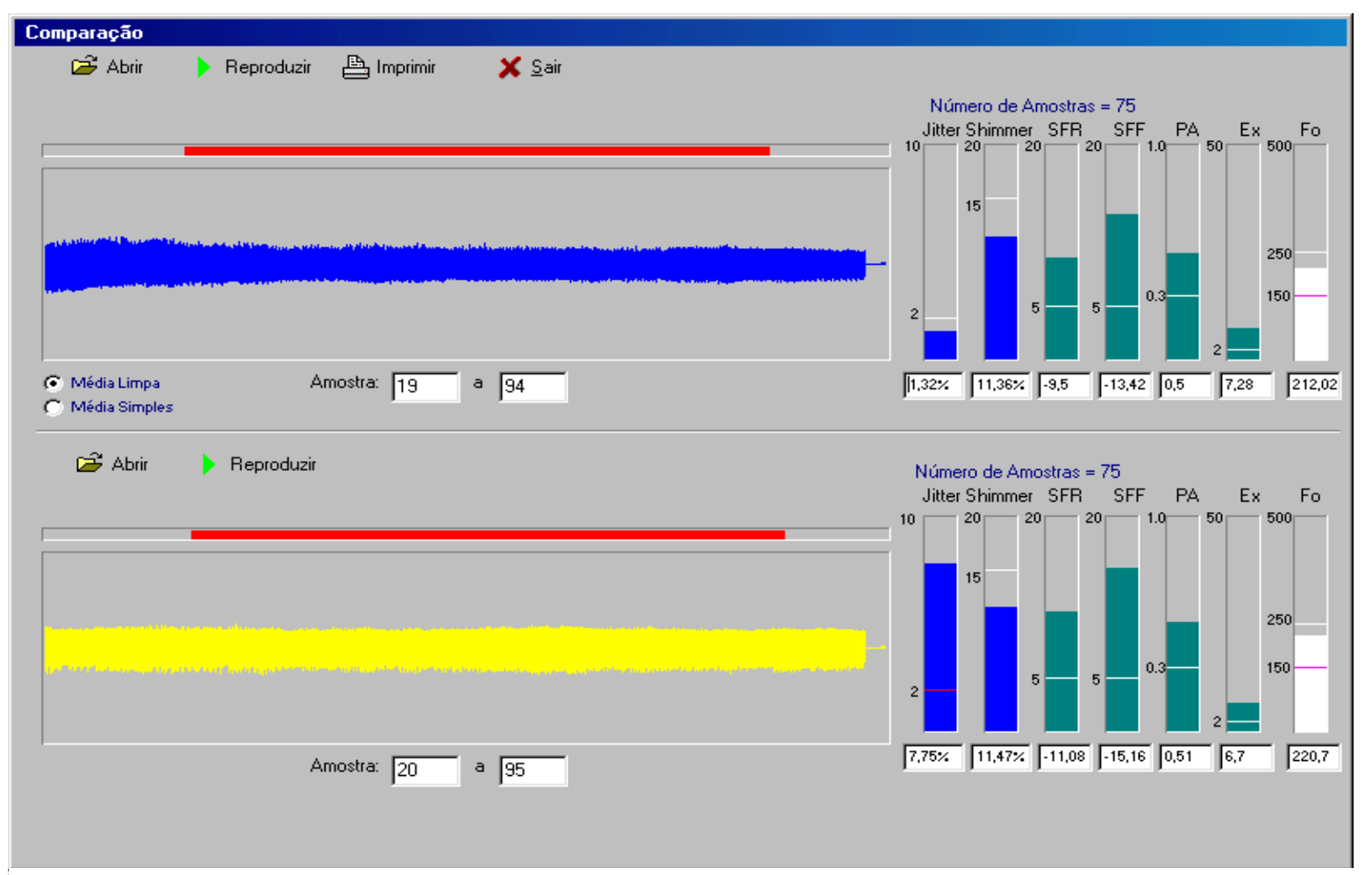

Figura 31 - Amostra do grupo feminino onde a porcentagem do parâmetro Jitter da vogal nasal foi maior que o da vogal oral 


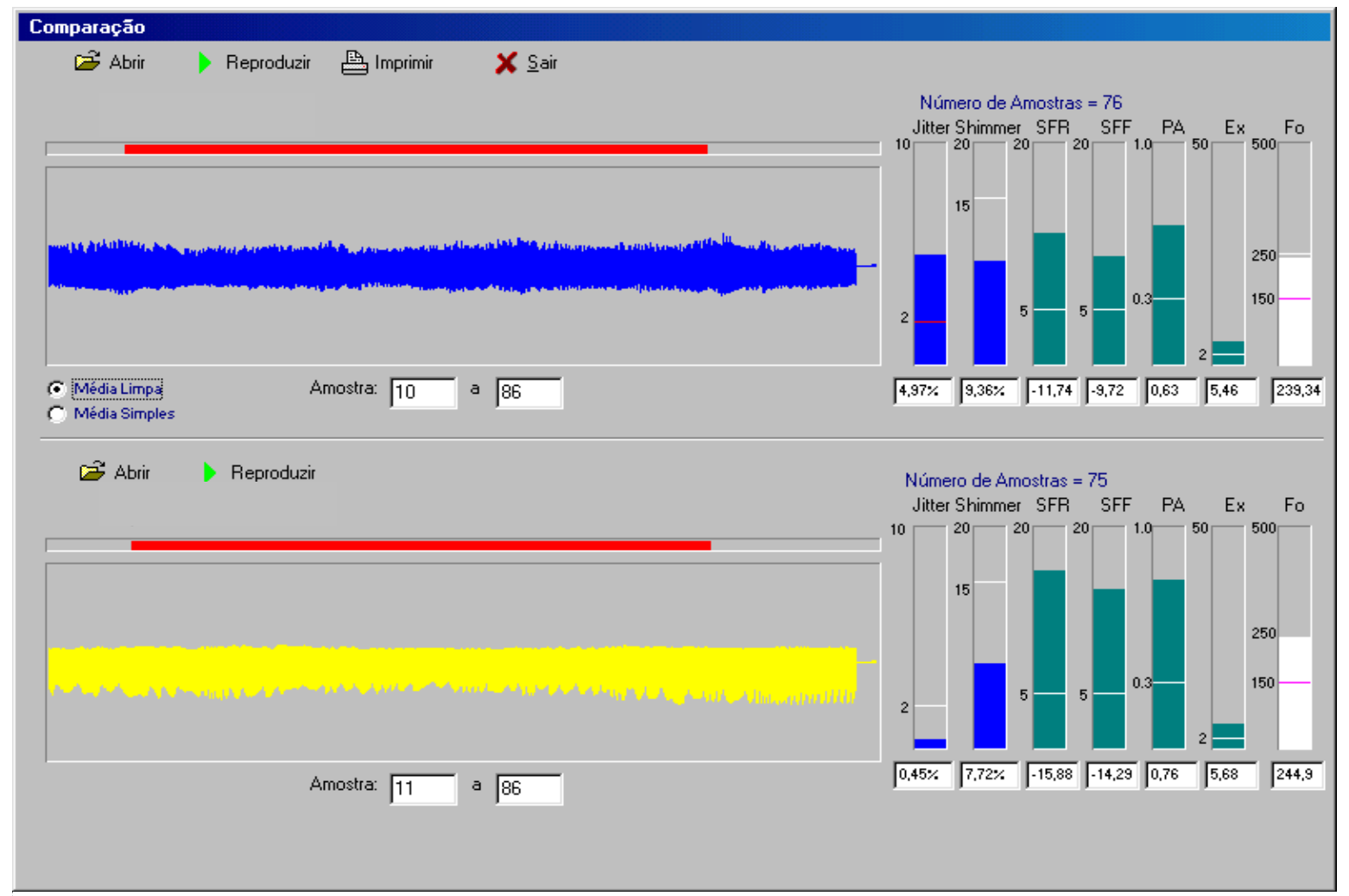

Figura 32 - Amostra do grupo temınıno onde a porcentagem do parämetro Jitter da vogal oral to1 bem maior que a da vogal nasal

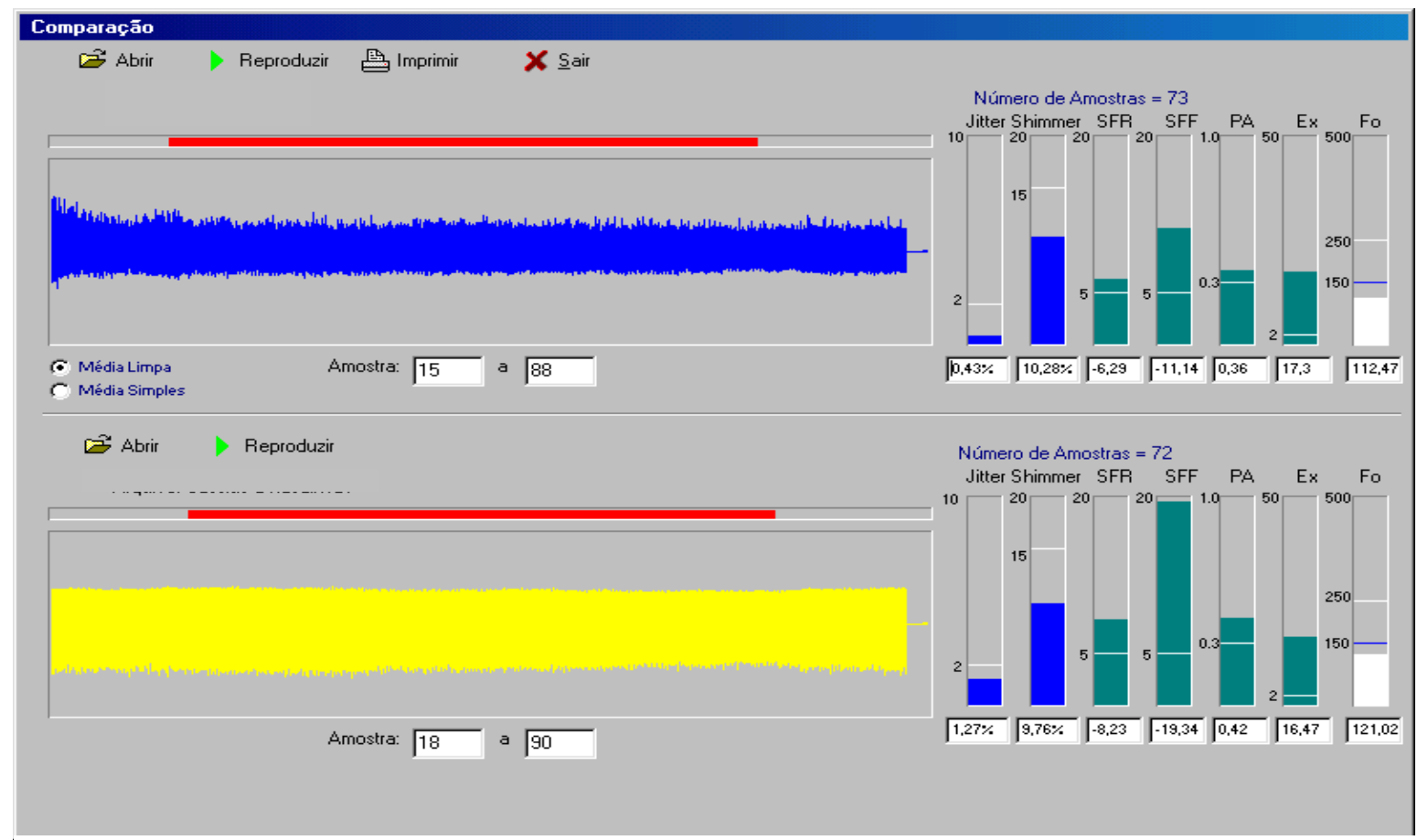

Figura 33 - Amostra do grupo masculino onde a porcentagem do parametro Jitter da vogal nasal to1 um pouco maior que a da vogal oral 


\section{2 - Recurso "Analisador"}

Ao analisar o espectro das vogais /a/ oral e /a/ nasal, observamos que no primeiro, segundo e terceiro formantes houve uma diminuição destes valores para as vogais nasais, concordando com os artigos de House \& Stevens (1956), Dickson (1962), Schwartz (1968) e Kataoka (1996).

House e Stevens (1956), descobriram ao estudar vogais nasais, que o efeito geral de incorporar o acoplamento nasal alarga e suaviza os picos no espectro vocálico. Este fato também pode ser observado na maior parte de nossas amostras.

No espectro das vogais nasais para os dois grupos estudados, surgem antiressonâncias (ou vales), como foi verificado pelo pesquisador Schwartz (1968). Também podemos observar, além dessas anti-ressônancias, picos e irregularidades acima do terceiro formante, como notou Kataoka (1996).

A tabela 5 exibe, para todas as amostras dos dois grupos, a região onde surgem as anti-ressonâncias.

Para o grupo masculino, 12 das 14 amostras das vogais nasais houve aumento na freqüência fundamental em relação as vogais orais, entretanto para o grupo feminino apenas 4 das 11 amostras apresentaram aumento da freqüência. Dickson (1962), supôs que o aumento na freqüência fundamental pode estar relacionado, não com a nasalidade, mas sim com o esforço aumentado que alguns indivíduos classificados como nasais necessitaram para produzir a fala.

Foi verificado na maior parte de nossas amostras, uma redução na intensidade dos harmônicos de alta freqüência, concordando com os achados na literatura. As figuras de 34 a 41 exibem o espectro vocálico das vogais: /a/ oral e /a/ nasal de algumas amostras. 
Tabela 5 - Análise das anti-ressonâncias para as amostras dos grupos femininos e masculinos

\begin{tabular}{|c|c|c|c|}
\hline $\begin{array}{c}\text { Amostras } \\
\text { (femininas) }\end{array}$ & $\begin{array}{c}\text { Anti-ressonâncias } \\
\text { (Hz) }\end{array}$ & $\begin{array}{c}\text { Amostras } \\
\text { (masculinas) }\end{array}$ & $\begin{array}{c}\text { Anti-ressonâncias } \\
(\mathbf{H z})\end{array}$ \\
\hline 1 & 4240 & 1 & 3630 \\
\hline 2 & 4550 & 2 & 2190 \\
\hline 3 & 2740 & 3 & 3260 \\
\hline 4 & 4380 & 4 & 2830 \\
\hline 5 & 3630 & 5 & 2470 \\
\hline 6 & 4570 & 6 & 3870 \\
\hline 7 & 2650 & 7 & 2480 \\
\hline 8 & 2580 & 8 & 2470 \\
\hline 9 & 2950 & 9 & 4080 \\
\hline 10 & 3350 & 10 & 3370 \\
\hline 11 & 4040 & 11 & 2050 \\
\hline & & 12 & 3930 \\
\hline & & 13 & 2530 \\
\hline & & 14 & 3330 \\
\hline
\end{tabular}




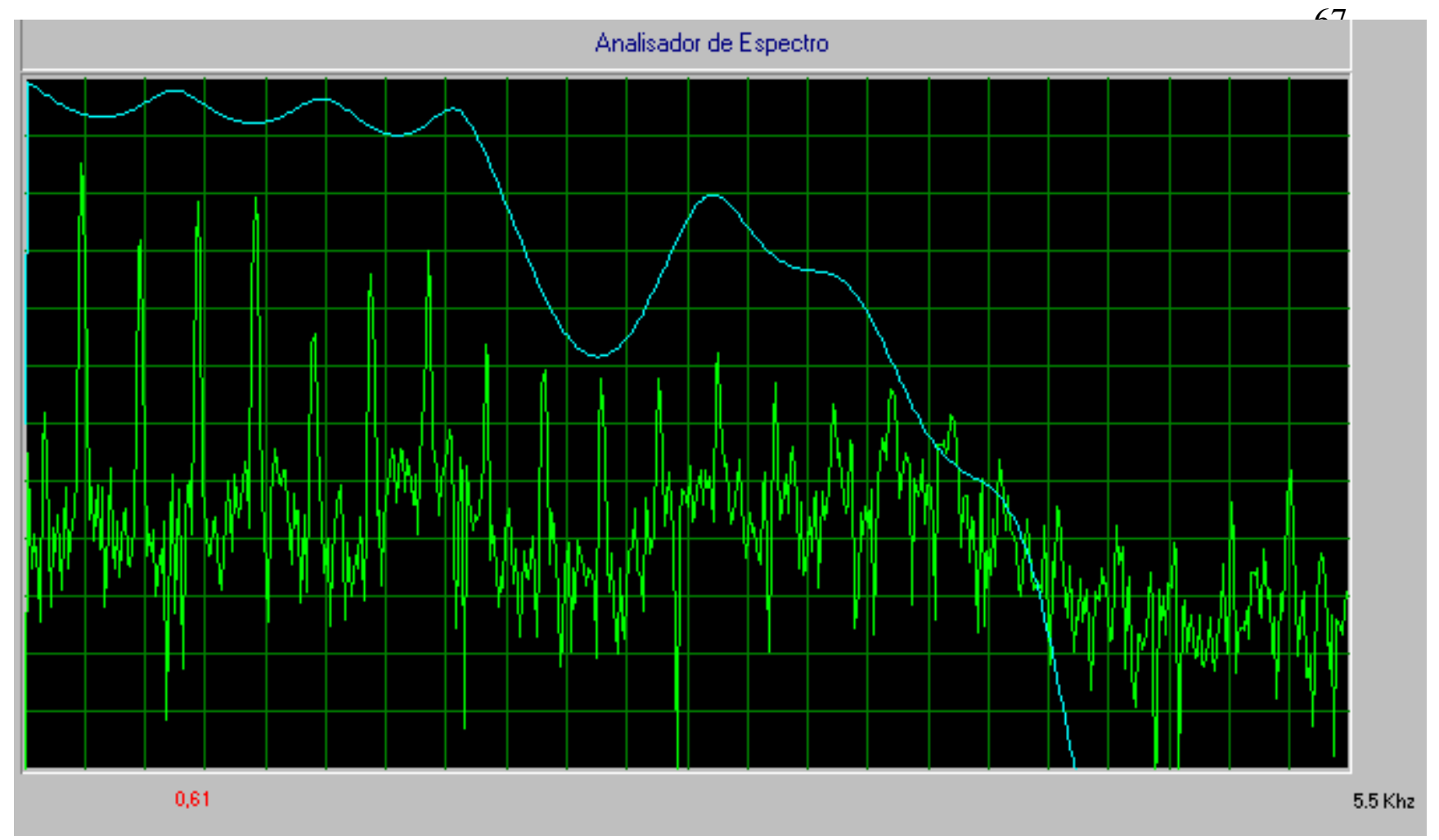

Figura 34- Espectro vocálico feminino pronunciando a vogal /a/ oral (A. M. S.)

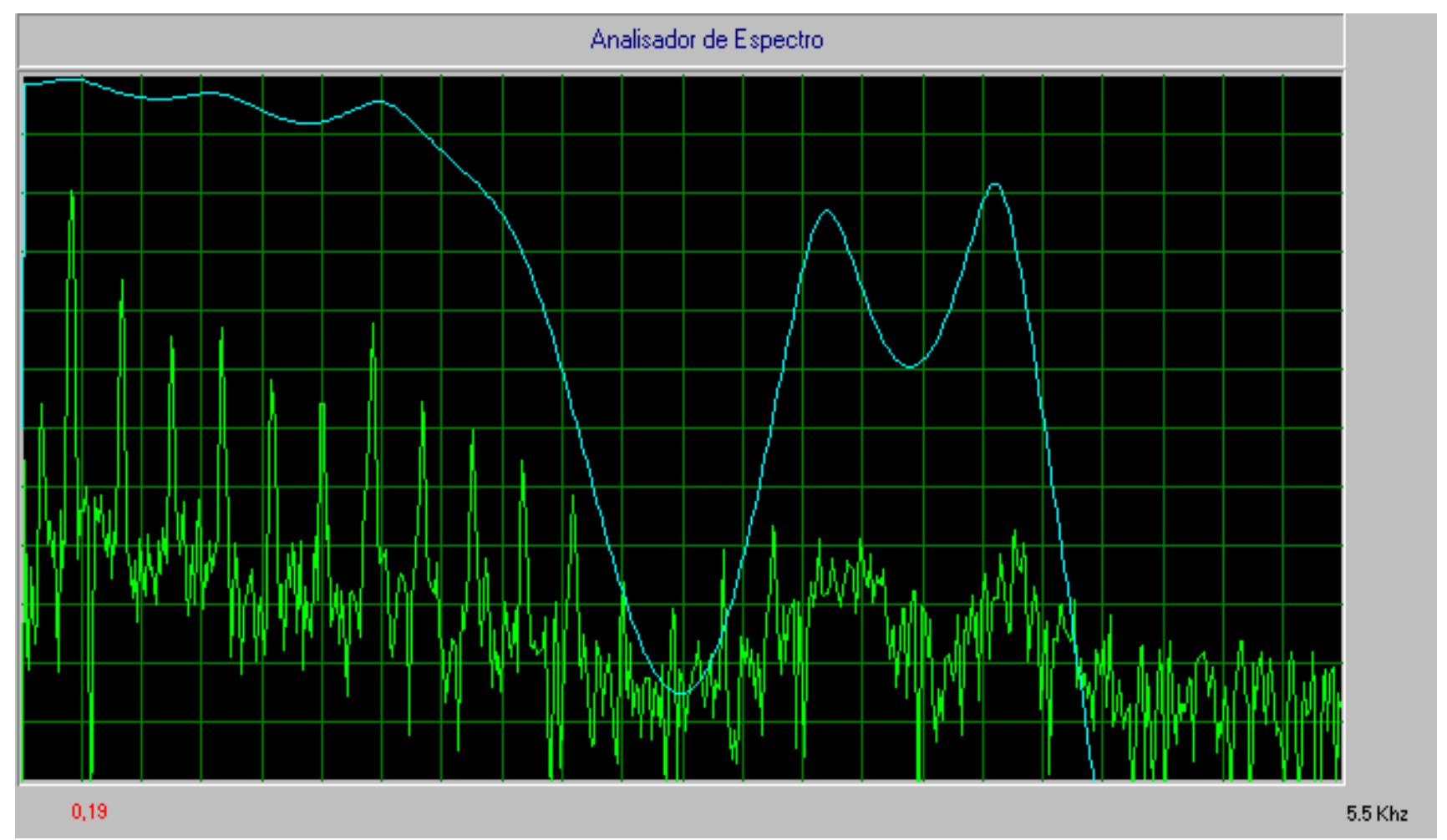

Figura 35 - Espectro vocálico feminino pronunciando a vogal /a/ nasal (A. M. S.) 


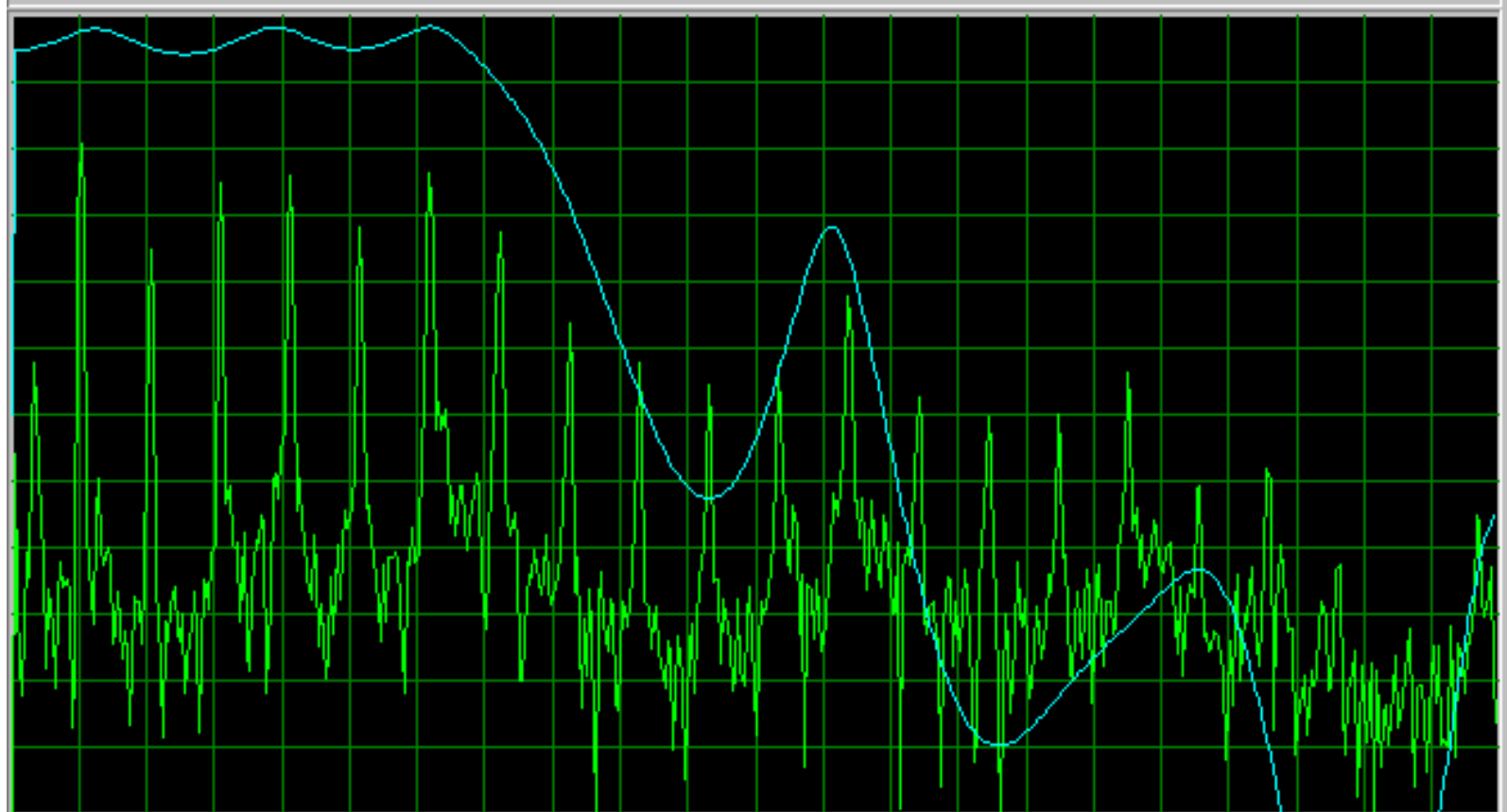

Figura 36 - Espectro vocálico feminino pronunciando a vogal /a/ oral (M. C. Q. S.)

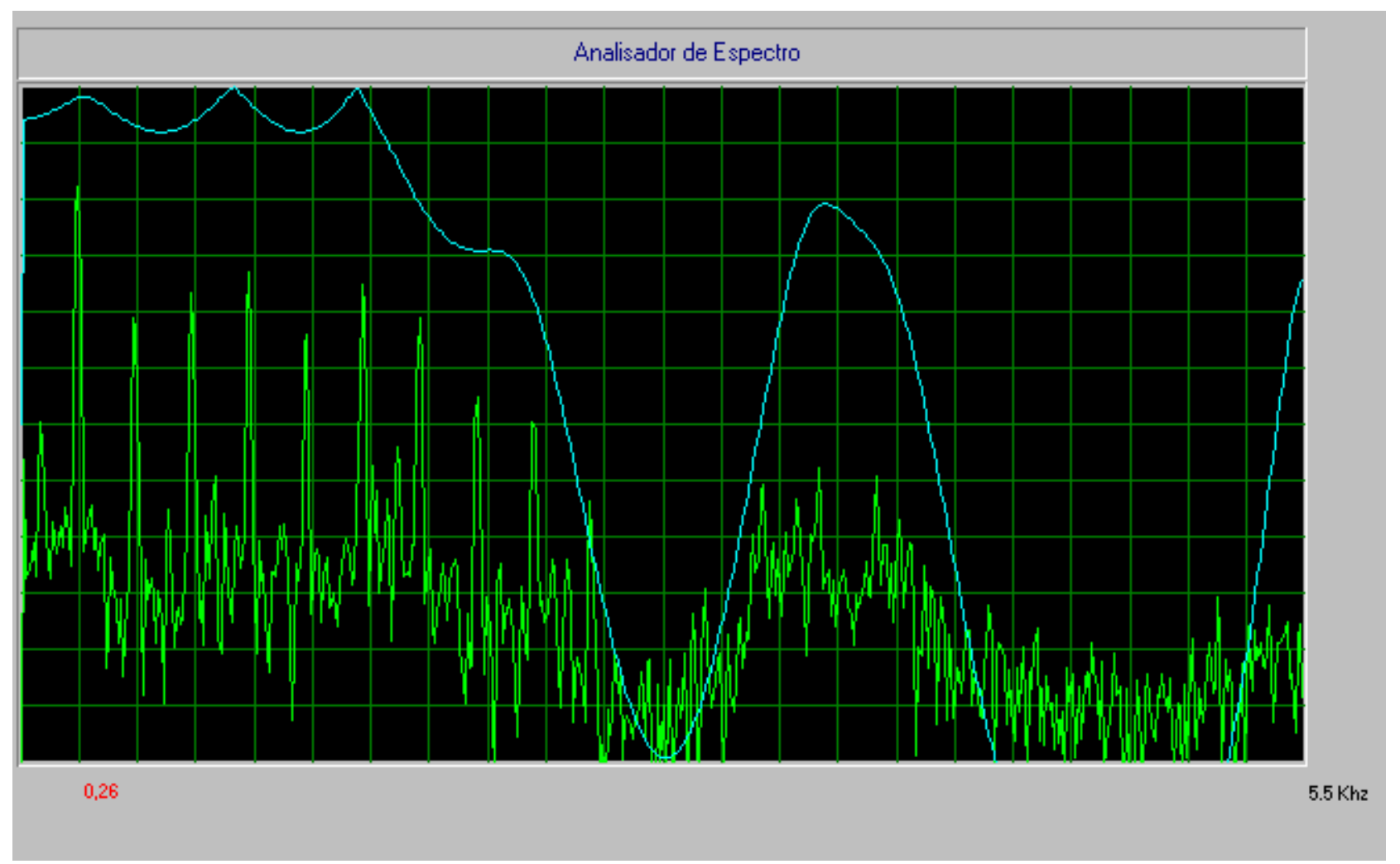

Figura 37 - Espectro vocálico feminino pronunciando a vogal /a/ nasal (M. C. Q. S.) 


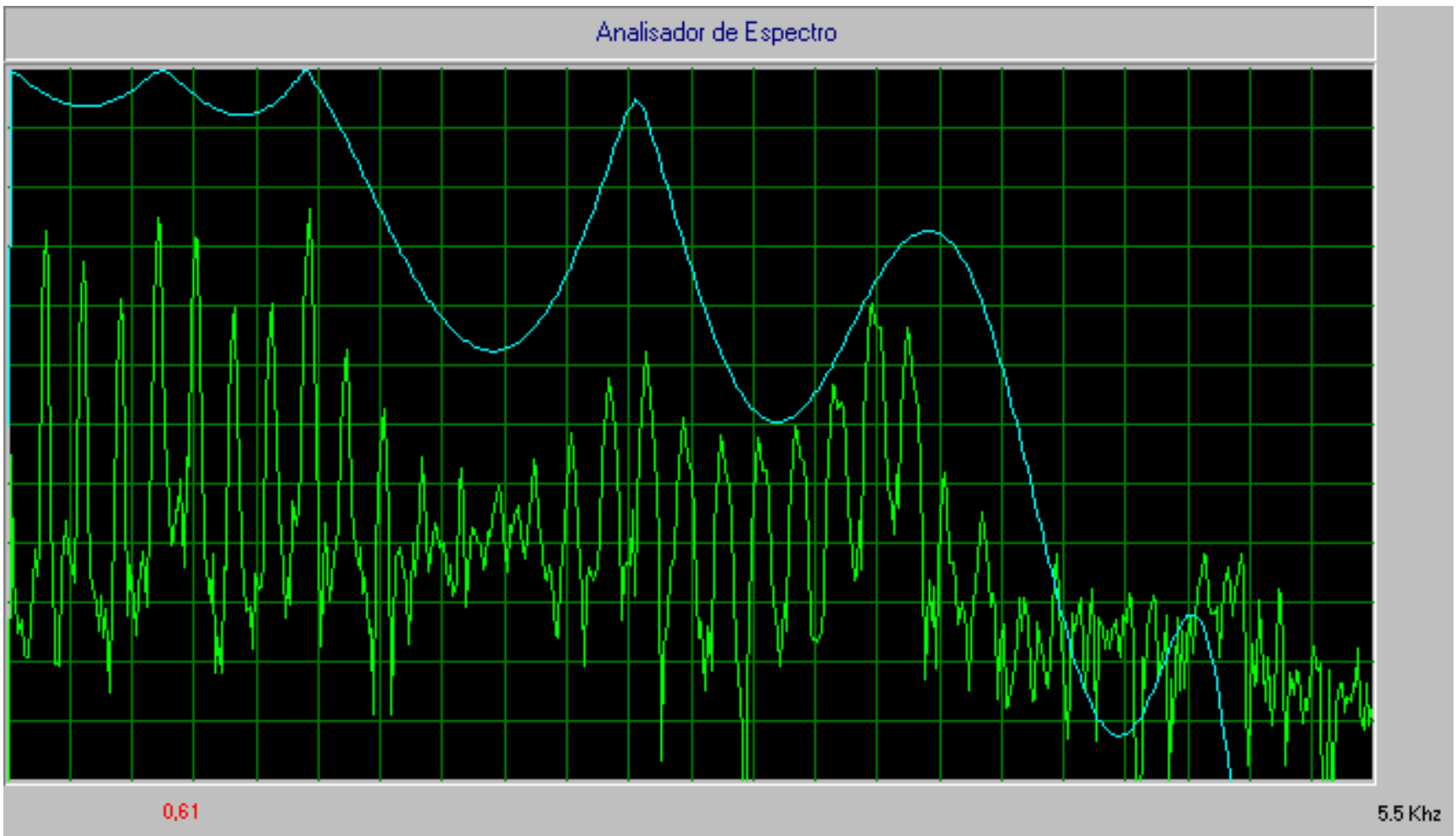

Figura 38 - Espectro vocálico masculino pronunciando a vogal /a/ oral (C. C. R.)

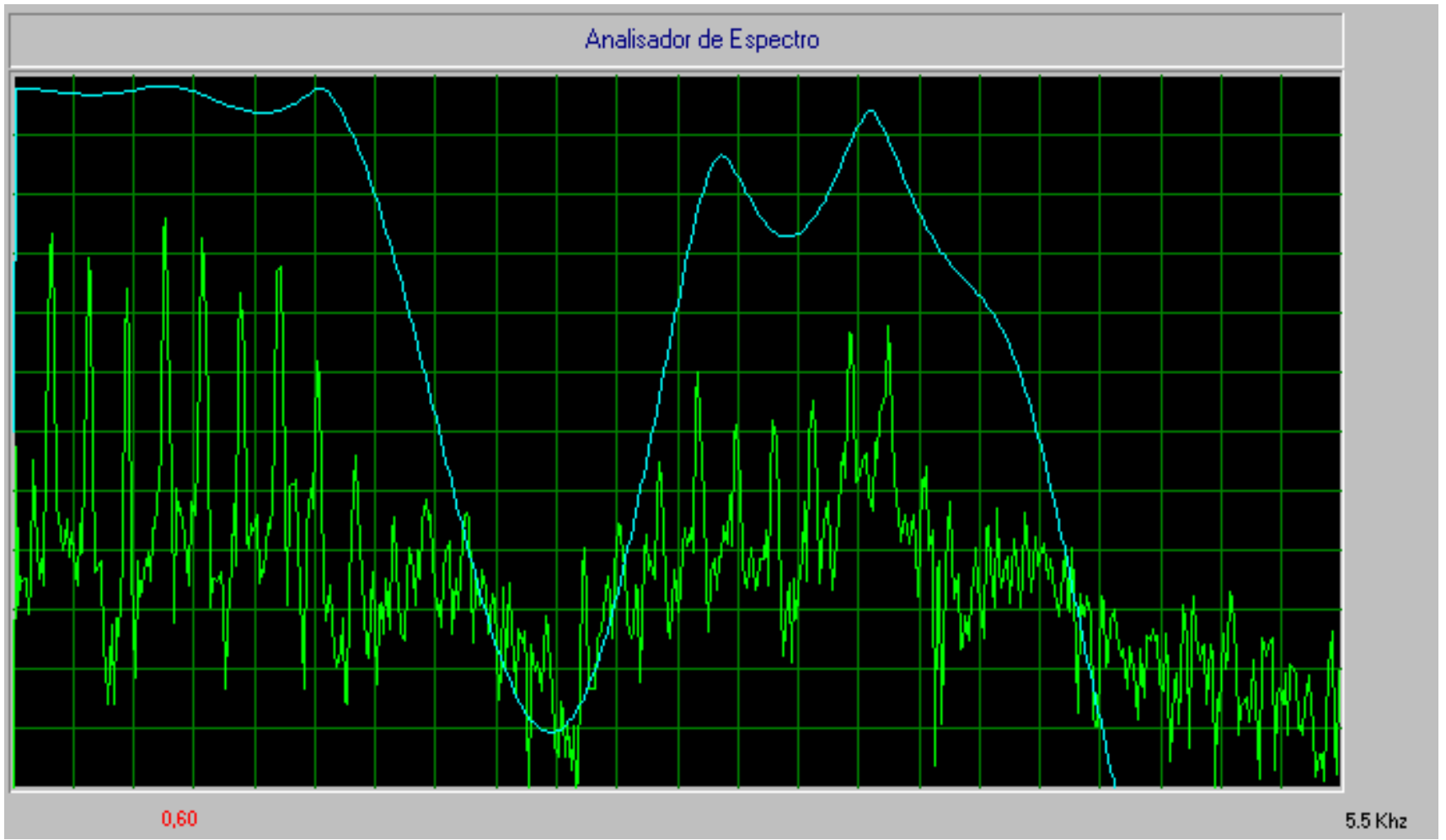

Figura 39 - Espectro vocálico masculino pronunciando a vogal /a/ nasal (C. C. R.) 


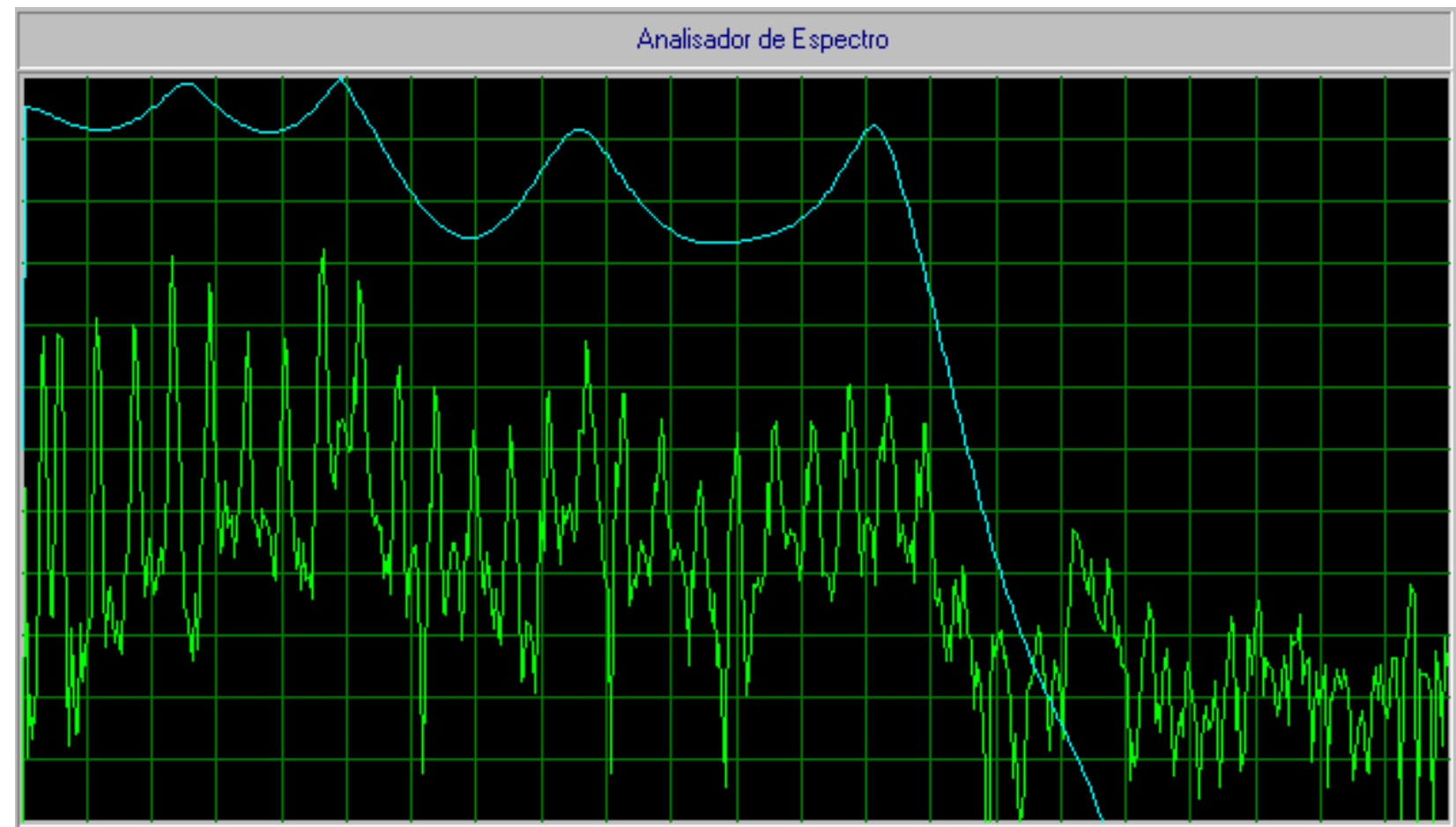

0,63

$5.5 \mathrm{Khz}$

Figura 40 - Espectro vocálico masculino pronunciando a vogal /a/ oral (C. R.)

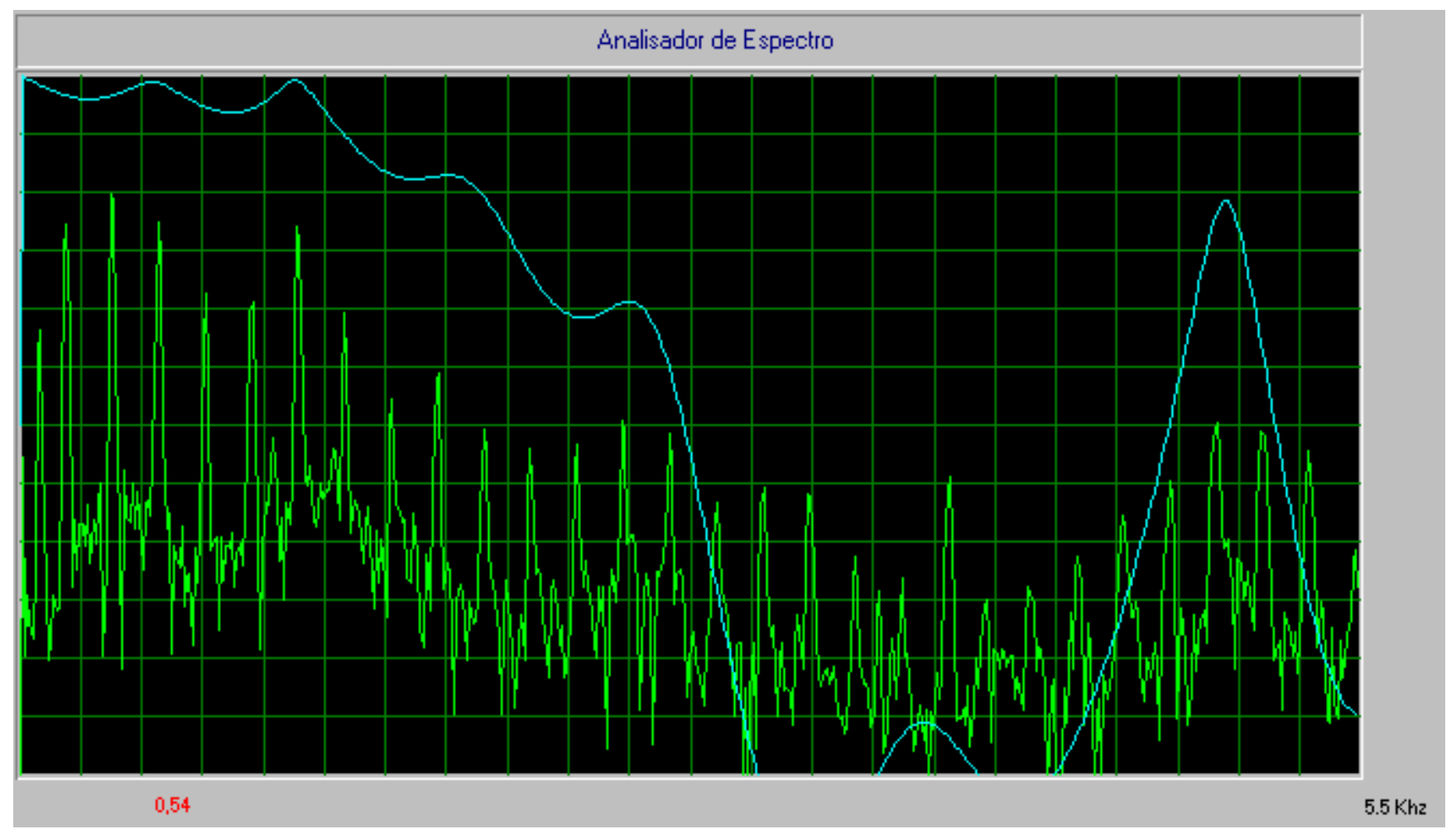

Figura 41 - Espectro vocálico masculino pronunciando a vogal /a/ nasal (C. R.) 
Podemos observar nas figuras de 30 a 32, que para o parâmetro Jitter, ocorreram grandes variações percentuais quando comparamos as vozes orais com as nasais. Por exemplo, na figura 30, o parâmetro Shimmer analisado para a vogal oral foi 8,81\% e para a vogal nasal foi 12,15\%. Para o parâmetro SFF esta diferença foi ainda menor, $-17,27 \%$ e $16,77 \%$, respectivamente. O mesmo ocorreu para $\mathrm{PA}, 0,45 \%$ para as vozes normais e 0,46\% para as nasais. Estas pequenas diferenças percentuais dos parâmetros para as duas maneiras de analisar a vogal /a/ pode ser observada na maior parte da nossa amostra. Apenas em dois casos ocorreram grandes variações. Para o número de amostras deste estudo, estas informações não foram suficientes para avaliar a nasalidade através do parâmetro Jitter.

Observando, por exemplo as figuras 40 e 41, vemos que a freqüência do primeiro formante para a vogal oral de um voluntário foi $630 \mathrm{~Hz}$ e para a vogal nasal esta freqüência diminuiu para $540 \mathrm{~Hz}$. Esta diminuição ocorreu na maior parte de nossas amostras. Nas figuras 38 e 39, por exemplo, pode ser observado que os picos no espectro da vogal nasal estão mais suavizados e mais largos.

Em todas as amostras analisadas para a vogal /a/ nasal surgiram anti-ressonâncias numa faixa de freqüência aproximadamente entre $2050 \mathrm{~Hz}$ a $4550 \mathrm{~Hz}$. Para o grupo feminino os valores destas anti-ressonâncias assumiram valores ainda maiores quando comparados com o grupo masculino. A média para o grupo feminino é de $3600 \mathrm{~Hz}$ enquanto para o grupo masculino a média encontra-se em $3030 \mathrm{~Hz}$. Esta diferença esta relacionada com o tamanho do trato vocal.

Contudo, o recurso "Analisador" foi um bom método para avaliar as características acústicas das vogais estudadas neste trabalho. 


\section{Capítulo 11 - Conclusão}

Utilizando os recursos "Comparação" e "Analisador" disponível no programa “Análise de Voz 2.3", foram analisadas as vogais /a/ oral e /a/ nasal para os grupos masculinos e femininos.

Verificou-se que as porcentagens de Jitter, calculadas através da "Comparação", obtiveram grandes variações tanto para as vogais orais quanto para as vogais nasais dos dois grupos estudados. Entretanto, para os parâmetros Shimmer; SFR; SFF; PA; Ex e Fo não ocorreram grandes variações.

A partir destas observações, foram realizadas tentativas de quantificar a nasalidade através do parâmetro Jitter.

Para as vogais orais do grupo feminino a variação percentual média de Jitter foi bem maior que do grupo masculino, $61,70 \%$ e $38,42 \%$ respectivamente. Ao passo que, para as vogais nasais a variação entre ambos os grupos foi menor, 68,26\% para o grupo feminino e $66,57 \%$ para o masculino.

Jitter não foi um bom parâmetro para tentar quantificar a nasalidade, devido ao reduzido número de amostras envolvidas neste trabalho. Serão necessários estudos com um número maior de amostras para verificar se este parâmetro poderá quantificar a nasalidade, além da avaliação perceptual simultânea de um especialista da voz. 
Analisando estas mesmas vogais, através do recurso "Analisador", concluiu-se que a freqüência do primeiro, segundo e terceiro formantes das vogais nasais diminuíram quando comparados com os espectros das vogais orais. Segundo Schwartz (1968) esta redução ocorreu devido à adição de características amortecedoras da cavidade nasal. Além disso, os picos do espectro vocálico das vogais nasais são mais suaves e mais largos.

Observou-se surgimento de anti-ressonâncias (regiões de intensidade muito reduzidas). Isto acontece quando um tubo (cavidade oro-faríngea) é acoplado a um outro tubo paralelo (cavidade nasal).

Estas anti-ressonâncias ocorreram numa faixa de freqüência entre $2050 \mathrm{~Hz}$ e 4550 Hz. Para o grupo feminino estas freqüências assumiram valores maiores do que para o grupo masculino. Esta diferença está relacionada ao tamanho do trato vocal.

Também pode-se observar no espectro das vogais nasais o surgimento de irregularidades acima do terceiro formante e uma redução na intensidade dos harmônicos de alta freqüência.

O vale no espectro de freqüências sugere a proposta de um novo parâmetro para quantização da nasalidade menos susceptível a artefatos presente nos medidores de nasalância atuais. Ressalta-se também que o custo de instrumentação associada seria muito menor.

Todos as observações, à respeito do espectro vocálico, estão em conformidade com os trabalhos encontrados na literatura. Acrescentando a estes resultados, as regiões onde surgiram as anti-ressonâncias demostraram ser um determinador eficiente para quantificar a nasalidade. 


\section{Referências Bibliográficas}

ANDRADE, L. M.O. et al. (2002). Medidas de perturbação da voz: um novo enfoque. Revista Fonoaudiologia, 2 v., n 2, 39-46 p. Dez.

ANDREASSEN, M. L. et al. (1991). Changes in vocal resonance and nasalization following adenoidectomy in normal children: preliminary findings. The Journal of Otolaryngology, 20 v., n 4, 237-242 p.

ANDREASSEN, M. L. et al. (1994). Aerodynamic, acoustic, and perceptual changes following adenoidectomy. Cleft Palate-Craniofacial Journal, 31v., n 4, 263-270 p. July.

AMABIS, J. M.; MARTHO, G. R. (1995). Investigando o corpo humano. Scipione.

BOONE, D. R.; McFARLANE S. C. (1994). A voz e a terapia vocal. 5.ed. Artes Médicas Sul Ltda.

BZOCH, K. R. (1997). Communicative disorders related to cleft lip and palate. 4.ed. 
CASTRO, S. V. (199?). Anatomia fundamental. 3.ed. McGraw-Hill do Brasil.

COLTON, R. H.; CASPER, J. K. (1996). Compreendendo os Problemas de Voz: uma Perspectiva Fisiológica ao Diagnóstico e ao Tratamento. Artes Médicas Sul Ltda.

CURTIZ, J.F. (1968). Acoustic of speech production and nasalization. In Cleft Palate and Communication. 27-60 p.

DÂGELO, J. G. (1997). Anatomia humana sistêmica e segmentar. 2.ed. Atheneu Editora de São Paulo.

DAVIS, S. B. (1979). Acoustic characteristics of normal and pathological voices. In: Lass N J, editor. Speech and Language: Advances in Basic Research and Pratice, New York: Academic Press. 1 v., 271-335 p.

DEAL, R. E., EMANUEL, F. W. (1978). Some waveform and spectral features of vowel roughness. Journal of Speech and Hearing Research. 250-264 p.

DELLER, J. R.; PROAKIS, J. G.; HANSEN, J. H. L. (1993). Discrete-time processing of speech signals. Editora Prentice-Hall do Brasil. Rio de Janeiro.

DICKSON, D. R. (1962). An acoustic study of nasality. Journal of Speech and Hearing Research. 5 v., n. 2, 103-111 p. June. 
ERHART, E. A. (1965). Elementos de anatomia humana. 2.ed. Atheneu Editora de São Paulo.

FROKJAER-JENSEN, B., PRYTZ, S. (1976). Registration of voice quality. B\& K Technical Review. 3-17 p.

FUKAZAWA, T., EL-ASSUOOTY, A., HONJO, I. (1988). A new index for evaluation of the turbulent noise in pathological voice. Journal of the Acoustical Society of America. 1189-1193 p.

GUYTON, A. C. (1988). Fisiologia humana. 6.ed. Guanabara Koogan.

HECKER, M. H. L., KREUL, E. J. (1970). Description of the speech of patients with cancer of the vocal folds. Part I: Measures of fundamental frequency. Journal of the Acoustical Society of America. 1275-1282 p.

HILLENBRAND, J., CLEVELAND, R. A., ERICKSON, R. L. (1994). Acoustic correlates of breathy vocal quality. Journal of Speech and Hearing Research. 769-778 p.

HIRAOKA, N., KITAZOE, Y. UETA, H., TANAKA, S., TANABE, M. (1984). Harmonicintensity analysis of normal and hoarse voices. Journal of the Acoustical Society of America. 1648-1651 p.

HOLLINSHEAD, W. H. (1991). Anatomia. 4.ed. Interlivros. 
HORII, Y. (1979). Fundamental frequency perturbation observed in sustained phonation. Journal of Speech and Hearing Research. 5-19 p.

HOUSE, A. S.; STEVENS, K. N. (1956). Analog studies of the nasalization of vowels. J. Speech Hear Disord, cap. 21, 218-232 p.

HUCHE, F. L.; Allali, A. (1999). A voz: anatomia e fisiologia dos órgãos da voz e da fala. 2. ed. Artes Médicas Sul Ltda.

KASUYA, H., OGAWA, S., MASHIMA, K., EBIHARA, S. (1986). Normalized noise energy as a acoustic measure to evaluate pathologic voice. Journal of the Acoustical Society of America. 1329-1334 p.

KATAOKA, R. et al. (1996). Spectral properties and quantitative evaluation of hypernasality in vowels. Cleft Palate-Craniofacial Journal. 33 v., n 1, Jan.

KOIKE, Y. (1973). Applications of some acoustic measures for the evaluation of laryngeal dysfunction. Studia Phonologica. 17-23 p.

KOIKE, Y., TAKAHASHI, H., CALCATERRA, T.C. (1977). Acoustic measures for detecting laryngeal pathology. Acta Otolaryngol. 105-117 p.

KOJIMA, H., GOULD, W. J., LAMBIASE, A., ISSHIKI, N. (1980). Computer analysis of hoarseness. Acta Otolaryngologica. 547-554 p. 
LABLANCE, G. R. et al. (1991). Advances in non-invasive measures of vocal acoustic.

Ear, Nose and throat Journal. 70 v., n 10, 678-684 p.

LADEFOGED, P. (1974). Elements of acoustic phonetics. The University of Chicago Press.

LEESON, T. S. (1970). Histologia. 2.ed. Atheneu Editora São Paulo.

MOLL, K. L. (1962). Velopharyngeal closure on vowels. Journal of Speech and Hearing Research. 5 v., n 1, 30-37 p. Mar.

LIEBERMAN, P. (1963). Some acoustics measures of the fundamental periodicity of normal and pathologic larynges. Journal of the Acoustics Society of America. 344-353 p.

MURRY, T., DOHERTY, E. T. (1980). Selected acoustic characteristics of pathologic and normal speakers. Journal of Speech and Hearing Research. 361-369 p.

PARKER, A. J. et al. (1989). An objective method of assessing nasality: a possible aid in the selection of patients for adenoidectomy. Clin. Otolaryngol. 14 v., 161-166 p.

PINHO, S. M. R.; CAMARGO, Z. (2001). Tópicos em voz. Guanabara Koogan.

ROMANES, G. J. (1976). Manual de anatomia prática. Atheneu Editora São Paulo. 
SANSONE, F. E., EMANUEL, F. W. (1970). Spectral noise levels and roughness severity ratings for normal and simulated rough vowels produced by adult males. Journal of Speech and Hearing Research. 472-488 p.

SCHWARTZ, M. F. (1968). The acoustic of normal and nasal vowel production. Cleft Palate Journal. 125-140 p.

SHOJI, K., et al. (1992). High-frequency power ratio of breathy voice. Laryngoscope. 267$271 \mathrm{p}$.

SHPRINTZEN, R. J.; Bardach, J. (1995). Anatomy and physiology of the palate and velopharyngeal structures. Cleft Palate Speech Management a Multidisciplinary Aprroach.

SPENCE, A. P. (1991). Anatomia humana básica. 2.ed. Manole Ltda.

TABITH, A. J. (1997). O esfincter velofaríngeo. Distúrbios da Comunicação São Paulo. 135-150 p. Jun.

TAKAHASHI, H., KOIKE, Y. (1975). Some perceptual dimensions and acoustical correlates of pathologic voices. Acta Oto-Laryngologica. 1-24 p.

TRINDADE, I. E.; Trindade, A. S. (1996). Avaliação funcional da inadequação velofaríngea. Tratamento das Fissuras Labiopalatinas. cap. 26, 223-235 p.

WARWICK, R., (19??). Gray anatomy. 35.ed. Guanabara Koogan. 
YUMOTO, E., GOULD, W. J., BAER, T. (1982). Harmonics-to-noise ratio as na index of the degree of hoarseness. Journal of the Acoustic Society of American. 1544-1549 p.

Zajac, D. J. et al. (1996). Aerodynamic and acoustic characteristics of a speaker with turbulent nasal emission: a case report. Cleft Palate-Craniofacial Journal. 33 v., n. 5, 400-404 p. Sept. 